OPEN ACCESS

Edited by:

Zhan $\mathrm{Hu}$,

Sun Yat-sen University, China

Reviewed by:

A. Rita Carrasco,

University of Algarve, Portugal

Andrés Payo,

British Geological Survey, The Lyell

Centre, United Kingdom

${ }^{*}$ Correspondence:

Wen L. Chen

wenlong.chen@cranfield.ac.uk

†Present address:

Peter Muller,

Syndicat Mixte du Bassin de Thau

(SMBT), Sète, France

Specialty section:

This article was submitted to

Coastal Ocean Processes,

a section of the journal

Frontiers in Marine Science

Received: 13 November 2021 Accepted: 20 December 2021

Published: 09 February 2022

Citation:

Chen WL, Muller P, Grabowski RC and Dodd N (2022) Green

Nourishment: An Innovative

Nature-Based Solution for Coastal Erosion. Front. Mar. Sci. 8:814589.

doi: 10.3389/fmars.2021.814589

\section{Green Nourishment: An Innovative Nature-Based Solution for Coastal Erosion}

\author{
Wen L. Chen ${ }^{1 *}$, Peter Muller ${ }^{1+}$, Robert C. Grabowski ${ }^{1}$ and Nicholas Dodd ${ }^{2}$ \\ ${ }^{1}$ School of Water, Energy and Environment, Cranfield University, Cranfield, United Kingdom, ${ }^{2}$ Faculty of Engineering, \\ University of Nottingham, Nottingham, United Kingdom
}

Coastal erosion poses an urgent threat to life and property in low-lying regions. Sand nourishment is increasingly used as a nature-based solution but requires significant natural resources and replenishment over time. In this study, a novel form of nourishment is explored that combines shoreface nourishment and seagrass restoration to mitigate coastal erosion (i.e., green nourishment). Using the coastal morphodynamic model Xbeach, the impact of seagrass planting on wave energy dissipation, sediment erosion and transport, and morphological evolution of a cross-shore profile was studied for mild wave conditions and an intense storm. Model results indicate that a seagrass meadow enhances the wave energy dissipation provided by a shoreface nourishment, and suggests that it may be particularly effective in sediment transport mitigation when implemented in a sheltered nearshore area. The shoreface nourishment reduced the wave height on the seagrass meadow, and reduced the rate of seagrass destruction by deposition or erosion above the grass height after the storm event. Green nourishment also reduced beach foreshore erosion caused by a simulated storm event. An alternative, more cost-effective planting technique using seagrass seeds was explored, which showed similar coastal erosion protection benefits for seagrass transplants. This modeling study found that green nourishment is potentially an effective nature-based solution for coastal erosion and flooding on sandy coasts, and future studies are recommended to evaluate its morphological, ecological and flood risk reduction benefits in the field.

Keywords: shoreface nourishment, seagrass restoration, coastal retreat, storm resilience, coastal defense

\section{INTRODUCTION}

Coastline retreat is a sign of the vulnerability of low-lying sandy coasts to erosion and sea level rise (Stronkhorst et al., 2018). This issue affects $70 \%$ of the world's sandy coasts and a large proportion of the United Kingdom's coastline experiences erosion rates higher than $0.1 \mathrm{~m} /$ year (30\% in England) (Masselink and Russell, 2008; Williams et al., 2018). The severe threat induced by the gradual degradation of dunes, beaches and foreshores causes flood risks to people living nearby, and damage to buildings or infrastructure in coastal cities and villages (Stronkhorst et al., 2018). Existing literature and IPCC scenarios point to an increase in sea level rise (SLR) (Nicholls et al., 2007; Hinkel et al., 2013) and the frequency and intensity of extreme events associated with 
waves (Menéndez and Woodworth, 2010; Izaguirre et al., 2011), resulting in a significant predicted increase in the number and severity of coastal flood events and erosion (Hinkel et al., 2013).

Measures for coastal protection often consist of engineering (i.e., hard) solutions such as breakwaters, dikes and groynes (Williams et al., 2018). However, hard sea defenses can exacerbate coastal erosion and cause adverse effects on the environment (Hamm et al., 2002). Therefore, there has been a shift away from hard coastal defenses to nature-based solutions. An alternative approach, commonly referred to as "Building with Nature," is to use natural materials such as sand, and to exploit the constructive forces of nature (i.e., currents and waves) to build and maintain natural flood defenses (Stronkhorst et al., 2018; Montgomery et al., 2019). In this vein, sand nourishments are increasingly used in the United Kingdom and Europe. Nourishments consist of collecting sand from offshore sandpits and placing the sand either directly on the beach or as a sand buffer on the eroding foreshore (van Duin et al., 2004), replenishing the beach and dissipating wave energy during storms (Stronkhorst et al., 2018). Over time, the deposited sand will be transported to and along the shore, providing an input to the coastal sediment budget. Such nature-based flood defenses provide several ecosystem services, including flood protection, recreation and nature conservation, in addition to long term intervention for SLR (Temmerman et al., 2013). They are considered to be unobtrusive coastal interventions with low costs and environmental impacts in comparison to traditional hard engineering (Bergillos et al., 2018). Shoreface nourishments are usually placed as relatively long $(2-10 \mathrm{~km})$ sand bodies, in depths ranging from Mean Sea Level (MSL) -10 to $-4 \mathrm{~m}$ (Huisman et al., 2019), which reduce wave energy approaching the shore, thus providing protection. However, as these nourishments suffer from relatively quick sand loss, they need to be replenished periodically (typical 310 years interval), implying significant costs and the need for large sand resources that many maritime countries do not possess (de Schipper et al., 2016).

Seagrass provides a potential nature-based solution to reduce wave-generated erosion and extend the timespans for coastal benefits at nourishment sites. Seagrass has historically been found in temperate and subtropical oceans around the world, but its distribution has been significantly impacted by direct and indirect human activity (e.g., dredging, pollution). Seagrass beds are ecologically important marine habitats (Boudouresque et al., 2021; da Ros et al., 2021) that stabilize sandy substrates through the binding effects of their roots and rhizomes and, through the hydrodynamic buffering capabilities of their leaves, dissipate wave energy, tidal currents and storm surges (Fonseca, 1994; Reidenbach and Thomas, 2018; Montgomery et al., 2019). A dense seagrass meadow is able to reduce wave height by $40 \%$ during storm events (Ondiviela et al., 2014). Seagrass restoration projects are progressing worldwide and show promising survival rate of the seagrass planting (Figure 1; Marion and Orth, 2010; Tanner and Parham, 2010; van Katwijk et al., 2016; Unsworth et al., 2019; Boudouresque et al., 2021). Whilst sheltered hydrodynamic conditions are typically recommended, the use of large transplants (Paulo et al., 2019) and biodegradable materials to contain the seeds and stabilize the plant during the initial period of planting significantly increases the survival rate (Irving et al., 2014; Tan et al., 2020; Gagnon et al., 2021). Using hessian seed bags anchored along strings to seabed (Figure 1C), a Zostera marina restoration site in the sea at Cornwall and Swansea (under tide of $7.68 \mathrm{~m}$ range) had a $94 \%$ survival rate after 10 months of seagrass planting (Unsworth et al., 2019). Seagrass transplanting using containers made of corn anchored by steel rods in the Adriatic Sea reached a $30 \%$ survival rate in a stormy winter (da Ros et al., 2021; Figure 1B). Seagrass plantings have been successful even along coasts exposed to high wave energy, i.e., coasts in Portugal (Paulo et al., 2019), South Australia (Tanner and Parham, 2010; Wear et al., 2010) and Cornwall (Unsworth et al., 2019). Integrating vegetation, mangroves and salt marshes into coastal defense has the potential to significantly cut the cost of coastal protection (van Zelst et al., 2021). A recent successful field construction of salt marsh (Baptist et al., 2021) and an analysis on historic data (Zhu et al., 2020) revealed the high efficiency of coastal wet-land as a nature-based flood defense even with long-term sea level rise, which sheds light on the hidden role of seagrass restoration in coastal protection.

"Green nourishment," i.e., the combination of sand nourishment and seagrass meadow restoration, has the potential to provide a nature-based and effective method to mitigate coastal erosion and flooding. Whilst numerous studies have investigated the impacts of nourishment and, separately, the survival and growth of seagrass restoration, so far none has investigated the impacts of green nourishment on coastal geomorphic and flooding impacts. In particular, the influence of the seagrass meadow's location, size, and planting technique on its ability to reduce wave energy and sediment transport when combined with a nourishment must be investigated to provide an indication on how the seagrass meadow and nourishment could be combined in order to maximize coastal protection and reduce erosion. The aim of this study is to use a modeling approach to explore how green nourishment affects cross-shore sediment transport and geomorphic dynamics using the coastal morphodynamic model XBeach (Roelvink et al., 2009). Specific objectives are to determine the impacts of seagrass location, size and planting technique on the evolution of cross-shore morphology and wave height, and the resilience of a green nourishment to storm events.

\section{MATERIALS AND METHODS}

The simulations were carried out using XBeach, which is a widely used model to predict waves, currents, sediment transport, and morphology change under various wave conditions (Roelvink et al., 2009). It is an open-source code that has been validated in a large number of cases for hydrodynamics and morphological changes (McCall et al., 2010; Dissanayake et al., 2014; Lashley et al., 2018; Roelvink et al., 2018). In this study, the cross-shore time-dependent short wave action balance equation on the scale of wave groups was solved using the $1 \mathrm{D}$ instationary "surfbeat" mode of XBeach. The infragravity (IG) wave motions and mean flow were driven by the radiation stress gradient in the non-linear shallow water equations. The JONSWAP (Joint North Sea Wave 
A

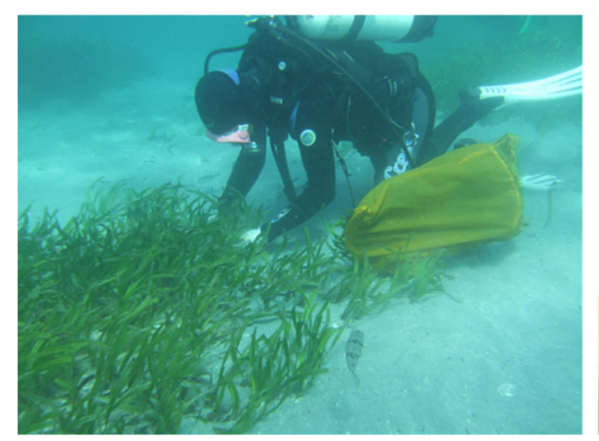

B

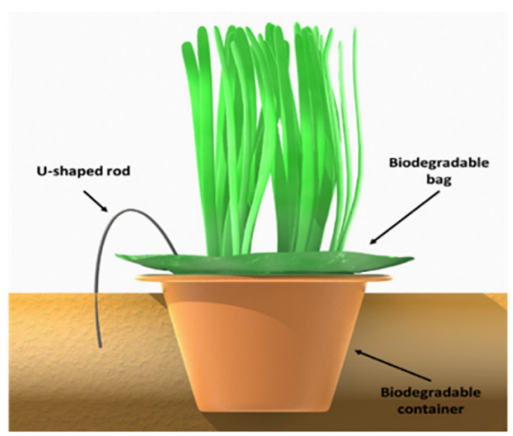

C

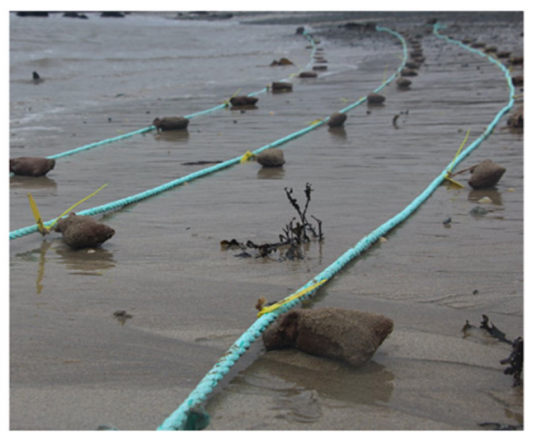

D

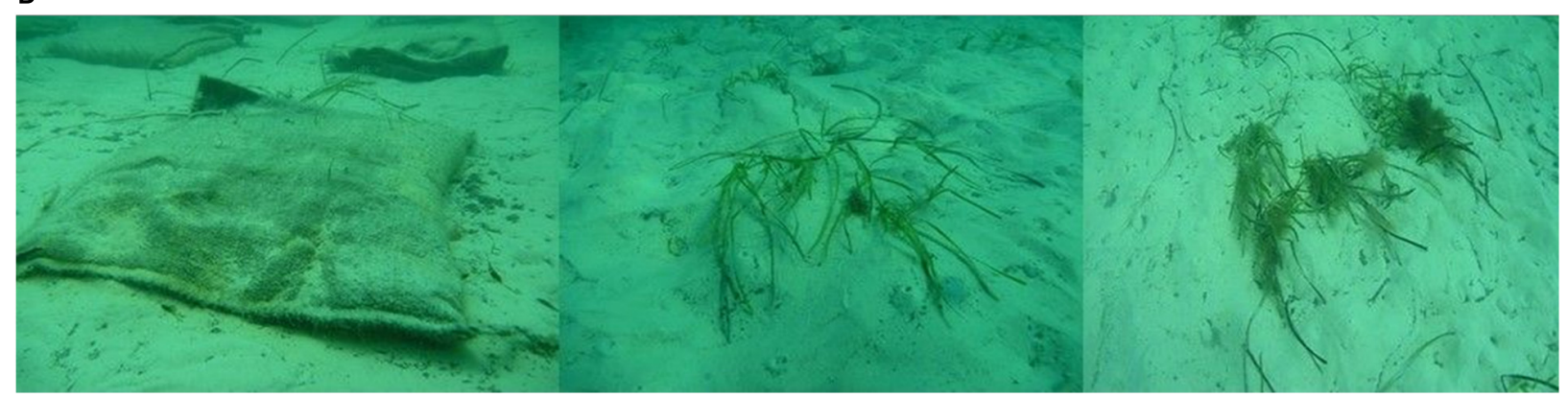

FIGURE 1 | (A) Seagrass transplant, CProject SEAGRASS.LI (photos by Chris Pickerell, Cornell Cooperative extension of Suffolk County, NY); (B) seagrass transplant with biodegradable container (da Ros et al., 2021); (C) seagrass planting with hessian seed bags, OProject Seagrass (photo taken in Porthdinllaen, Wales); (D) the germination and growth of hessian seed bag, @SARDI (photos by Jason Tanner).

Project) spectral boundary conditions were applied along the offshore boundary. In approaching the coast, the wave energy was dissipated by wave breaking (Roelvink, 1993), bottom friction (van Dongeren et al., 2013; Quataert et al., 2015) and vegetation (Mendez and Losada, 2004). The short wave dissipation due to vegetation was calculated using the formulation of Mendez and Losada (2004), i.e., a function of the local wave height and several vegetation parameters at the designated seagrass location. The vegetation is notionally schematized as a rigid cylinder, with parameters including vegetation stem height $\left(a_{h}\right)$, diameter $\left(b_{\mathrm{v}}\right)$, and density $\left(\mathrm{N}_{\mathrm{v}}\right)$. Multiple layers of vegetation could be introduced to define for instance mangroves, which have dense roots and sparse stems. Here one vertically uniform vegetation layer was used to simulate seagrass. The seagrass was introduced through a characteristic file which defines the seagrass parameters and a vegetation location file. To account for the progressive growth of the seagrass, the vegetation module of XBeach was modified in this study to allow a time-dependent vegetation parameter. This modification adds a time parameter " $\mathrm{T}_{\mathrm{v}, \mathrm{m}}$ " to represent the mature period of the seagrass. In this study, growth rate was modeled as linear, but any growth rate curve can be implemented. The damping effect of vegetation not only affects the dissipation of wave energy, but also the infragravity waves and mean flow, and is modeled as a drag force added to the momentum equation (van Rooijen et al., 2016). The dissipation and drag effect of vegetation were present only where vegetation was defined in the location file. The XBeach with vegetation module (van Rooijen et al., 2016) has been successfully applied to evaluate the global role of vegetation in flood defense (van Zelst et al., 2021).

The sediment transport is simulated using a depth-averaged advection-diffusion equation where the van Thiel-van Rijn formulation is adopted for the calculation of sediment flux (van Rijn, 2007; van Thiel de Vries, 2009). One important mechanism for the onshore sediment flux is the wave non-linearity (Chen and Dodd, 2019), which is the change of wave shape due to wave shoaling and breaking. As a wave shoals, the wave shape changes from sinusoidal to an increasingly skewed shape, with a narrow-accentuated crest followed by a broad flat trough. Toward and after breaking, the wave shape progressively changes to a highly asymmetrical shape, i.e., a pitched-forward shape with a steep front face. As a result, the time histories of both nearbed flow velocity and acceleration also become asymmetric; i.e., the skewness (velocity skewness) and asymmetry (acceleration skewness) also increase. The increase of skewness and asymmetry of the wave as it propagates to the coast leads to increased onshore sediment flux. Here, the effect of change in wave shape on the sediment transport was approximated as an extra velocity term in the advection-diffusion equation, i.e.,

$$
u_{a}=\gamma_{u a}\left(S_{k}-A_{s}\right) u_{r m s},
$$

with $S_{k}$ denoting the wave skewness, $A_{s}$ the wave asymmetry, and $u_{r m s}$ the root mean square wave orbital velocity near bed. A higher value for $u_{a}$ will simulate a stronger onshore sediment flux. Recent studies show that the parameter $\gamma_{u a}$ should take a 

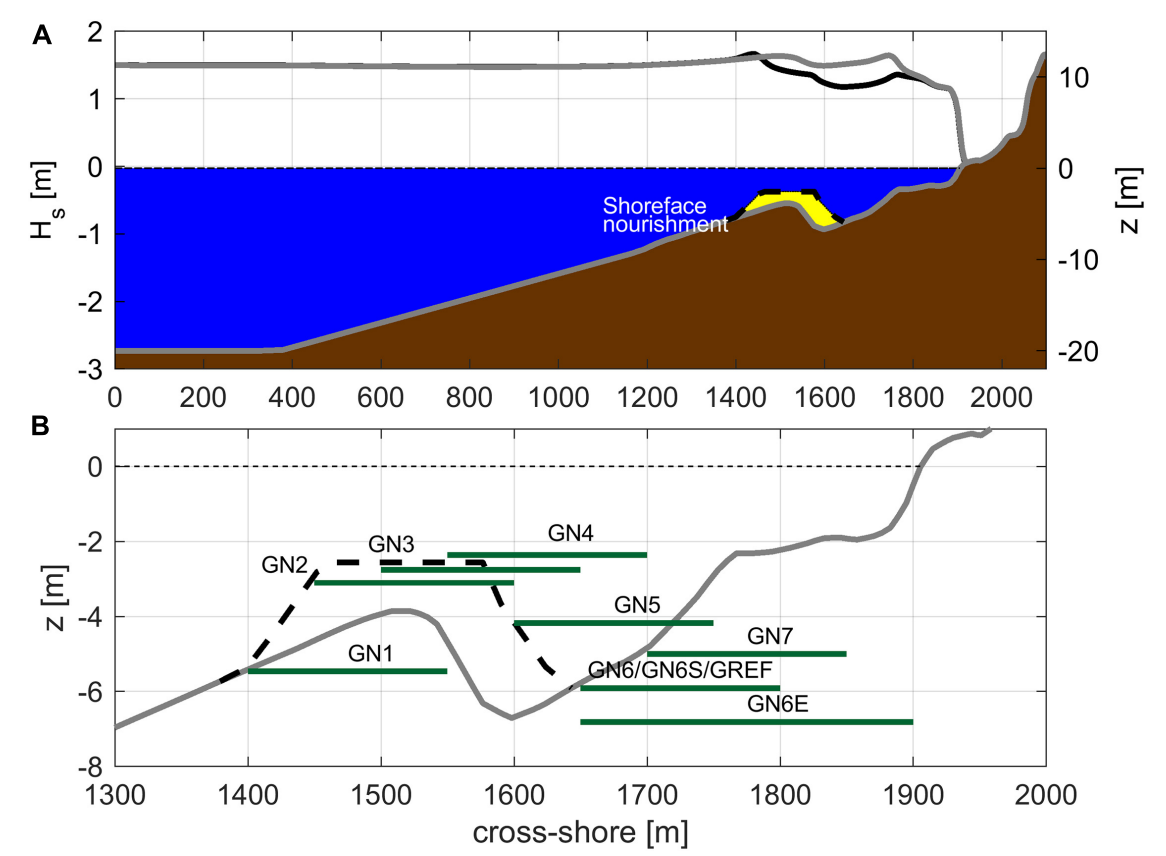

FIGURE 2 | Geometry showing: (A) nourishment on top of a nearshore sand bar and the significant wave height profile under mild wave condition $\left(H_{m}=1.5 \mathrm{~m}\right.$, $T=8 \mathrm{~s}$ ), with gray line for wave height for the reference (REF) and black line for wave height for the nourishment reference (SN); (B) location and length of seagrass meadows.

higher value than the default $\left(\gamma_{u a}=0.1\right)$ to correctly simulate the beach erosion (Elsayed and Oumeraci, 2017). Here, a $\gamma_{u a}$ value of 0.3 is taken (Jin et al., 2021). Seabed updating results from the Exner equation, i.e., convergence/divergence of sediment flux leads to deposition/erosion. The avalanching scheme is introduced to update the foreshore face of the dune to account for the slumping of sandy materials, where two separate critical slopes for dry and wet points are used. Sand is exchanged in between adjacent cells once this critical slope is exceeded. All parameters in XBeach take default value unless specified.

\section{RESULTS}

\section{Geometry and Runs}

The geometry consists of a beach connecting a region of constant depth $20 \mathrm{~m}$, on which there is a longshore uniform sand bar (top of the bar at $x=1,520 \mathrm{~m}$ ). At mean sea level, the shoreline is located at $x=1,905 \mathrm{~m}$. A shoreface nourishment of $400 \mathrm{~m}^{3} / \mathrm{m}$ sand was placed on top of the sand bar (Figure 2). Both the native sand and nourishment have median grain size of $0.3 \mathrm{~mm}$ and porosity of 0.4 . The sediment characteristic and seabed profile represented typical Dutch coast (i.e., Kijkduin, Holland; Stronkhorst et al., 2018). The common eelgrass (Zostera marina) was chosen for the study because it is widely distributed. Its characteristics, such as height at maturity $\left(a_{h}=50 \mathrm{~cm}\right)$, drag coefficient, stem diameter $\left(\mathrm{b}_{\mathrm{v}}=1 \mathrm{~cm}\right)$, density $\left(\mathrm{N}_{\mathrm{v}}=1,000 / \mathrm{m}^{2}\right)$ and growth rate, were obtained from the literature (Fonseca, 1994; Tyler-Walters, 2008; Tanner and Parham, 2010; Folkard, 2011). In total 26 simulations were performed, including a reference (REF) case without nourishment or seagrass, a geomorphic reference (GREF) case without nourishment but with seagrass, and a shoreface nourishment (SN) case with the nourishment but without seagrass. The experimental simulations included seven green nourishment cases (GN1-7) with seagrass planting located at the nourishment or closer to the shore, a green nourishment with extended seagrass meadow (GN6E), and a green nourishment with seed planting technique (GN6S) (Table 1). Mature seagrass was assumed to be planted at the beginning of the simulation unless seed planting technique was applied in which a linear growth curve was adopted for seagrass parameters. The seagrass meadow covered $150 \mathrm{~m}$ in the cross-shore direction except for GN6E which covered 250 $\mathrm{m}$. The sensitivity of green nourishment to wave conditions was tested (GN6W1-6) by varying wave height from $H_{m}=1.5 \mathrm{~m}$ to $H_{m}=4.5 \mathrm{~m}$ and wave period from $T=8 \mathrm{~s}$ to $T=11 \mathrm{~s}$. The effect of seagrass parameters was studied (GN6a1-4 and GN6n1-4) by varying $a_{h}$ from 10 to $90 \mathrm{~cm}$ and $N_{v}$ from 200 to $1,800 / \mathrm{m}^{2}$. All simulations lasted for 100 days, except in cases REF, GREF, SN, GN6, and GN6E, where a 1 week storm event ( $H_{m}=5 \mathrm{~m}, T=12 \mathrm{~s}$ ) was performed following the 100 days simulation to investigate the resilience of green nourishment to storm attack. The wave climate implemented into the model is based on the typical United Kingdom and Dutch coasts' wave climates. It is characterized by average significant wave height oscillating between 1 and $2.5 \mathrm{~m}$ and a wave period ranging from 6 to $10 \mathrm{~s}$, while the typical winter storms are characterized by wave heights of 4 to $5 \mathrm{~m}$ and a wave period ranging from 10 to 12 s (Wijnberg, 2002; Sembiring et al., 2015; Dhoop and Mason, 2018). A gradually refined grid toward the coast with maximum 
TABLE 1 | Simulation runs tested the impacts of nourishment, the location of a seagrass meadow, the planting techniques, seagrass meadow length, and mild vs. storm waves.

\begin{tabular}{|c|c|c|c|c|c|c|c|c|c|c|}
\hline \multirow[t]{2}{*}{ Cases } & \multirow{2}{*}{$\begin{array}{c}\text { Nourishment } \\
\text { location }\end{array}$} & \multirow{2}{*}{$\begin{array}{c}\text { seagrass planting } \\
\text { location }\end{array}$} & \multicolumn{3}{|c|}{ Seagrass parameters } & \multirow{2}{*}{$\begin{array}{l}\text { Seagrass } \\
\text { planting } \\
\text { technique }\end{array}$} & \multicolumn{3}{|c|}{ Wave conditions } & \multirow{2}{*}{$\begin{array}{c}\text { Storm event } \\
\begin{array}{c}\left(H_{\mathrm{m}}=5 \mathrm{~m},\right. \\
T=12 \mathrm{~s})\end{array}\end{array}$} \\
\hline & & & $a_{h}$ & $\mathbf{b}_{\mathrm{v}}$ & $\mathbf{N}_{\mathrm{v}}$ & & $\mathbf{H}_{\mathrm{m}}$ & $\mathbf{T}$ & duration & \\
\hline REF & \multirow[t]{2}{*}{ N/A } & N/A & $\mathrm{N} / \mathrm{A}$ & $\mathrm{N} / \mathrm{A}$ & $\mathrm{N} / \mathrm{A}$ & $\mathrm{N} / \mathrm{A}$ & \multirow[t]{12}{*}{$1.5 \mathrm{~m}$} & \multirow[t]{12}{*}{$8 s$} & \multirow[t]{26}{*}{100 days } & \multirow[t]{3}{*}{7 day } \\
\hline GREF & & $(1,650 \mathrm{~m}, 1,800 \mathrm{~m})$ & $50 \mathrm{~cm}$ & $1 \mathrm{~cm}$ & $1,000 / \mathrm{m}^{2}$ & Mature plant & & & & \\
\hline SN & \multirow[t]{24}{*}{$\begin{array}{l}(1,379 \mathrm{~m} \\
1,673 \mathrm{~m})\end{array}$} & $\mathrm{N} / \mathrm{A}$ & $\mathrm{N} / \mathrm{A}$ & N/A & $\mathrm{N} / \mathrm{A}$ & $\mathrm{N} / \mathrm{A}$ & & & & \\
\hline GN1 & & $(1,400 \mathrm{~m}, 1,550 \mathrm{~m})$ & \multirow[t]{15}{*}{$50 \mathrm{~cm}$} & \multirow[t]{23}{*}{$1 \mathrm{~cm}$} & \multirow[t]{19}{*}{$1,000 / \mathrm{m}^{2}$} & \multirow[t]{8}{*}{ Mature plant } & & & & \multirow[t]{5}{*}{$\mathrm{N} / \mathrm{A}$} \\
\hline GN2 & & $(1,450 \mathrm{~m}, 1,600 \mathrm{~m})$ & & & & & & & & \\
\hline GN3 & & $(1,500 \mathrm{~m}, 1,650 \mathrm{~m})$ & & & & & & & & \\
\hline GN4 & & $(1,550 \mathrm{~m}, 1,700 \mathrm{~m})$ & & & & & & & & \\
\hline GN5 & & $(1,600 \mathrm{~m}, 1,750 \mathrm{~m})$ & & & & & & & & \\
\hline GN6 & & \multirow{2}{*}{$\begin{array}{l}(1,650 \mathrm{~m}, 1,800 \mathrm{~m}) \\
(1,700 \mathrm{~m}, 1,850 \mathrm{~m})\end{array}$} & & & & & & & & 7 day \\
\hline GN7 & & & & & & & & & & N/A \\
\hline GN6E & & \multirow{8}{*}{$\begin{array}{l}(1,650 \mathrm{~m}, 1,900 \mathrm{~m}) \\
(1,650 \mathrm{~m}, 1,800 \mathrm{~m})\end{array}$} & & & & & & & & 7 day \\
\hline GN6S & & & & & & Seeds & & & & \multirow[t]{15}{*}{$\mathrm{N} / \mathrm{A}$} \\
\hline GN6W1 & & & & & & \multirow[t]{14}{*}{ Mature plant } & $2 \mathrm{~m}$ & $8.5 \mathrm{~s}$ & & \\
\hline GN6W2 & & & & & & & $2.5 \mathrm{~m}$ & 9s & & \\
\hline GN6W3 & & & & & & & $3 \mathrm{~m}$ & $9.5 \mathrm{~s}$ & & \\
\hline GN6W4 & & & & & & & $3.5 \mathrm{~m}$ & $10 \mathrm{~s}$ & & \\
\hline GN6W5 & & & & & & & $4 \mathrm{~m}$ & $10.5 \mathrm{~s}$ & & \\
\hline GN6W6 & & & & & & & $4.5 \mathrm{~m}$ & $11 \mathrm{~s}$ & & \\
\hline GN6a1 & & & $10 \mathrm{~cm}$ & & & & $1.5 \mathrm{~m}$ & $8 \mathrm{~s}$ & & \\
\hline GN6a2 & & & $30 \mathrm{~cm}$ & & & & & & & \\
\hline GN6a3 & & & $70 \mathrm{~cm}$ & & & & & & & \\
\hline GN6a4 & & & $90 \mathrm{~cm}$ & & & & & & & \\
\hline GN6n1 & & & \multirow[t]{4}{*}{$50 \mathrm{~cm}$} & & $200 / m^{2}$ & & & & & \\
\hline GN6n2 & & & & & $600 / \mathrm{m}^{2}$ & & & & & \\
\hline GN6n3 & & & & & $1,400 / \mathrm{m}^{2}$ & & & & & \\
\hline GN6n4 & & & & & $1,800 / \mathrm{m}^{2}$ & & & & & \\
\hline
\end{tabular}
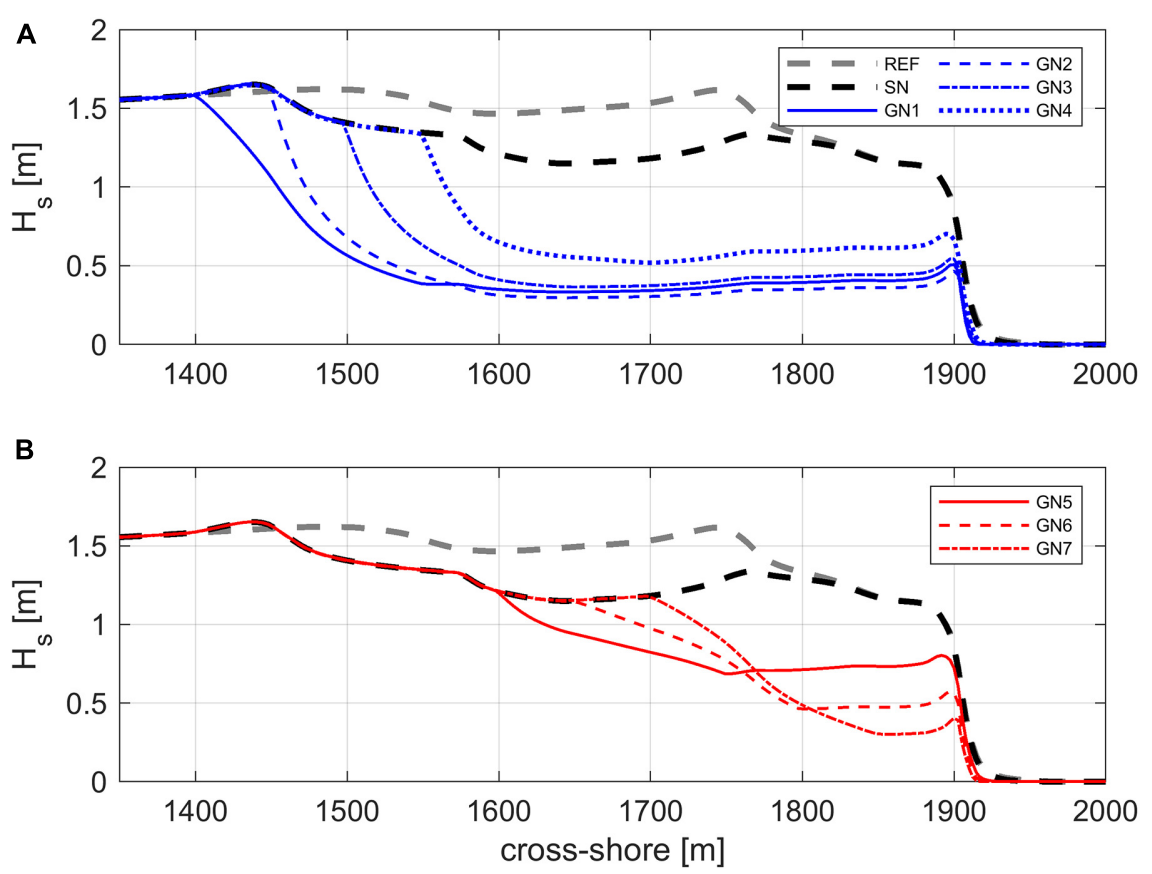

FIGURE 3 | Cross-shore wave height distribution under mild wave (i.e., $H_{m}=1.5 \mathrm{~m}, T=8 \mathrm{~s}$ ) for: (A) case REF, SN, GN1-4; and (B) case GN5-7. 
cell size of $15 \mathrm{~m}$ at the offshore boundary and minimum cell size of $1 \mathrm{~m}$ in the nearshore region was selected considering a balance between accuracy and calculation burden. The maximum Courant number is given as 0.9 and a morphological acceleration factor of 10 is defined.

Under the mild wave condition $\left(H_{m}=1.5 \mathrm{~m}, T=8 \mathrm{~s}\right)$, the gray profile for the REF case showed the incident waves beginning to break on the sandbar $(x=1,520 \mathrm{~m})$, and then more pronounced breaking near shore $(x=1,745 \mathrm{~m})$ (Figure 2A). The nourishment (SN) intensified the wave breaking on the bar and shifts seaward the breaking point to $x=1,440 \mathrm{~m}$, which led to a reduced wave height shoreward, compared to the REF case, covering approximately $400 \mathrm{~m}$ in the cross-shore direction. A maximum drop of $22 \%$ of wave height was observed at shoreward side of the nourishment. Consequently, the shore breaking of $\mathrm{SN}$ case has a lower height than that of the REF case, i.e., $1.336 \mathrm{~m}$ compared with $1.615 \mathrm{~m}$, and at a slightly shoreward location $(x=1,764 \mathrm{~m})$.

\section{The Evolution of Green Nourishment and Effect of Seagrass Meadow Location}

The combination of shoreface nourishment and seagrass planting significantly reduced the wave height (Figures 3, 4). This impact was particularly strong when the location of the seagrass meadow coincided with the wave breaking zone (i.e., at bar breaking region and shore breaking region for $\mathrm{SN}$, Figures 2, 3). For all GN cases, there was a rapid decrease in $H_{s}$ at start of the seagrass bed (see Figures 3, 4). This reduction was particularly rapid for GN1-4. In these cases, the plantings were entirely or partially on the nourishment and coincided to a greater or lesser extent with the bar breaker region. For GN1-3, $H_{s}$ diminished to a similar, post-planting level $\left(H_{s} \approx 0.35 \mathrm{~m}\right)$, which extended until the waves began to break again closer to the shore (at about $x=1,897 \mathrm{~m}$ ). For GN4-5, $H_{s}$ was also reduced by the planting, but because the local depth increased on the more shoreward section of the planting, $H_{s}$ reached a larger post-planting constant value $\left(H_{s} \approx 0.55\right.$ and $\left.0.7 \mathrm{~m}\right)$, which extended until the shore break. In the final two cases, GN6 and GN7, the wave height decay showed a different cross-shore pattern. The plantings were located closer to shore, in the shallowest areas coinciding with the shore breaking region, and so, once again, there was a combined effect of breaking and the planting, which resulted in smaller post-planting $H_{s}$ values.

The green nourishment provided the maximum dissipative effect when the vegetation region coincided with the bar breaker zone (GN1-3). For example, the seagrass meadow of GN2 was located on the nourishment in the area with the greatest wave height induced by the nourishment (SN, Figure 2) and led to a maximum reduction of $1.3 \mathrm{~m}$ in the wave height by the shoreward edge of the planting compared with the REF case, accounting for $80.3 \%$ of the REF wave height (Figures $\mathbf{3 A}, \mathbf{4 A}$ ). The strong turbulence and high wave orbital velocities associated with the breaker zone could pose a high risk of erosion for seagrass. Thus, results from GN6 and GN7, which cover the shoaling and breaking zone of shore breaking of SN case, are particularly interesting, because they lead to a reduction of $0.9 \mathrm{~m}(73.8 \%$, see Figure 4B) wave height at the shore breaking region, and, for
GN7, a particularly small at the shore. At the shoreline, the wave reduction of green nourishment is up to $100 \%$, which is because the seaward shift of the wave uprush at the coast induced by the wave attenuation.

Seagrass is able to effectively attenuate long period wave motion, i.e., the infragravity wave (Figure 5). Here the infragravity waves were generated by the variation in the water surface time series (Roelvink et al., 2009). Seagrass is responsible for the reduction of peak IG wave height. Among GN1-7, GN1 leads to the most prominent reduction, i.e., from $0.44 \mathrm{~m}$ in REF to $0.20 \mathrm{~m}$ in GN1. Under mild wave condition, the attenuation effect of seagrass on IG wave height is not as significant as on the incident wave height (Figures 3, 4), with a maximum reduction of $54.5 \%$ on IG wave height compared with a $80.3 \%$ reduction on incident wave height. Variation in the attenuation effect on IG waves is big between GN1-4 but small in between GN4-7. Nourishment also leads to a minor reduction of peak IG wave height. A similar seaward shift is observed for the uprush of IG wave at the shoreline.

Onshore sediment flux was observed for SN and GN1-7 cases as waves shoal and break (Figure 6A). In contrast, for the REF case, there was relatively little onshore sediment movement within the offshore region. Furthermore, shoreward in the REF case, offshore sediment flux was observed shoreward, peaking at $x=1,750 \mathrm{~m}$, probably induced by the return flow after breaking. Strong offshore sediment flux was observed at the coast for both REF and SN cases, which is induced by the combined effect of strong undertows during shore wave breaking and the backwash from the infragravity wave run-up (Figure 6A). Nourishment resulted in greater onshore sediment flux, especially on the nourishment itself, and also reduced the offshore sediment flux at the shore. For GN1-7 cases, the offshore sediment flux measured at the coast was almost one order of magnitude smaller than that of the REF and SN cases, as most of the incident wave energy was dissipated by the nourishment and the vegetation. The attenuation of the infragravity waves by the seagrass also contributes to the reduction of offshore sediment flux at the shore. At GN6 and GN7, the sediment fluxes at the seagrass meadow were significantly lower than that at GN2, suggesting less turbidity and better light condition in the water (Figure 6B). Compared with GN2, seagrass was located in a more sheltered environment in GN6 and GN7.

For green nourishment, the seabed stayed stable in the region immediately shoreward of the seagrass meadow and erosion at the shore is reduced compared to REF and $\mathrm{SN}$ in all cases (Figure 7). Bed change offshore was reduced most in case GN1, where the seagrass was located centrally on the nourishment, and at the shore in GN7, which had the most shoreward planting. Under mild wave conditions, onshore migration of the nearshore sand bar was observed as sand being eroded at the seaward side and deposited at shoreward side (i.e., in between $x=1,400 \mathrm{~m}$ and $x=1,650 \mathrm{~m}$ ). Considerable erosion was observed at the foreshore of beach (i.e., for $x>1,905 \mathrm{~m}$ ), which resulted from the strong offshore sediment flux induced by undertow as waves wash over the beach. For SN, the nourishment led to stronger onshore sand migration, which was due to the increased onshore sediment flux induced by amplified wave non-linearity on top 

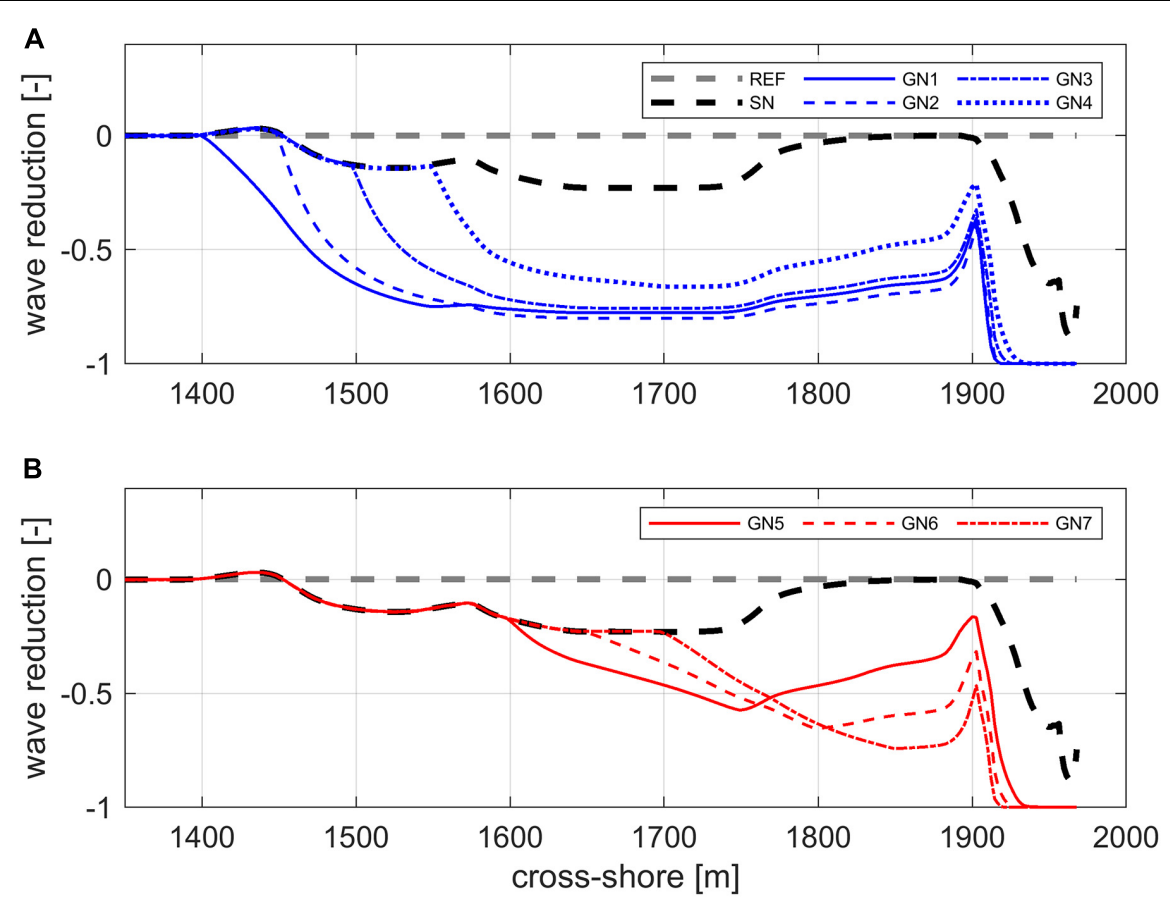

FIGURE 4 | Wave height reduction (i.e., wave height difference compared with the REF case) under mild wave for: (A) case SN, GN1-4; and (B) case GN5-7.
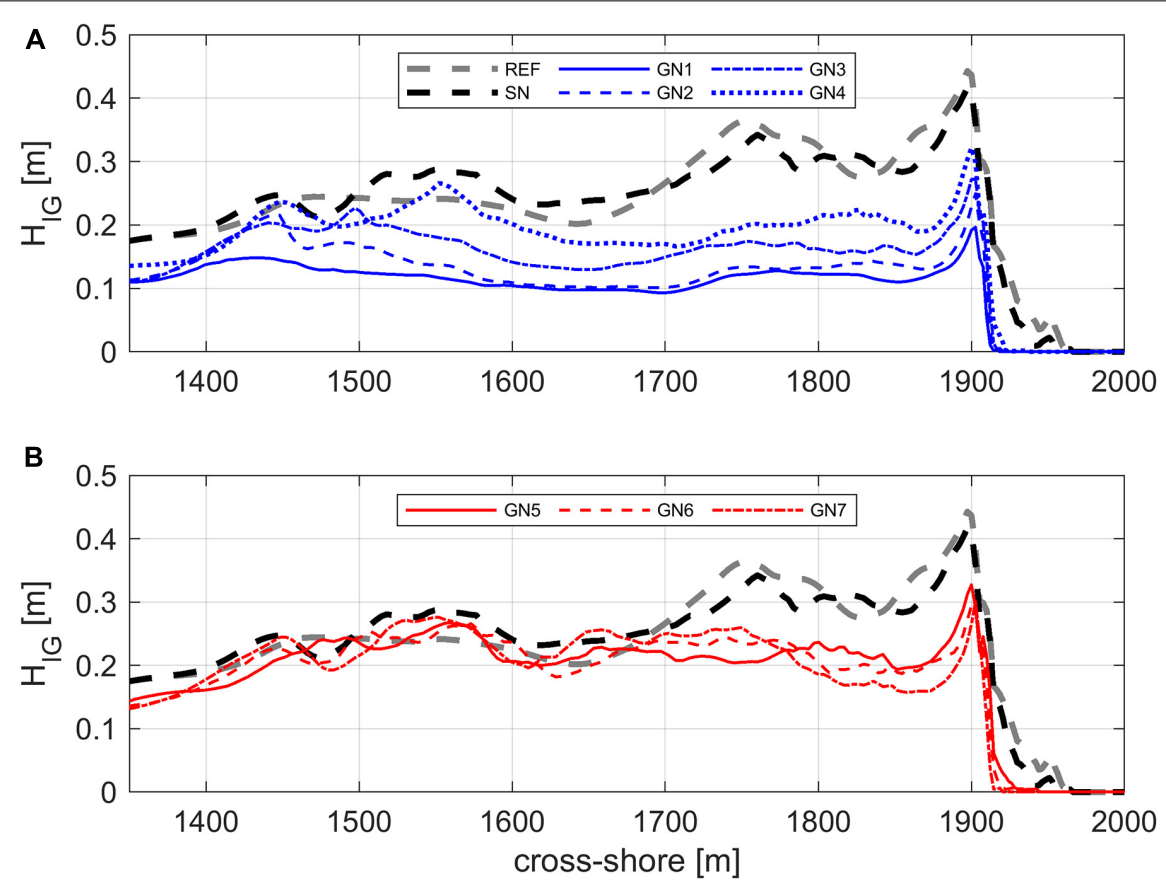

FIGURE 5 | Cross-shore infragravity wave height $\left(H_{\mid G}\right)$ distribution under mild wave (i.e., $H_{m}=1.5 \mathrm{~m}, T=8 \mathrm{~s}$ ) for: (A) case REF, SN, GN1-4; and (B) case GN5-7.

of the nourishment (Chen and Dodd, 2019). For SN, a stable seabed was observed in between 1,650 and 1,750 $\mathrm{m}$ at the end of 100 days of simulation. As mentioned, little change was observed for GN1-7 immediately shoreward of the seagrass meadow, in contrast to the active bathymetry change over the whole shoaling and breaking zone of the REF case. GN1 seems to have the most stable seabed shoreward of seagrass meadow. However, more than half the seagrass meadow encounters disturbance of either erosion or deposition as revealed by the bury ratio analysis (i.e., $\Delta z_{b} / a_{h}$ the ratio of changed seabed divided by 

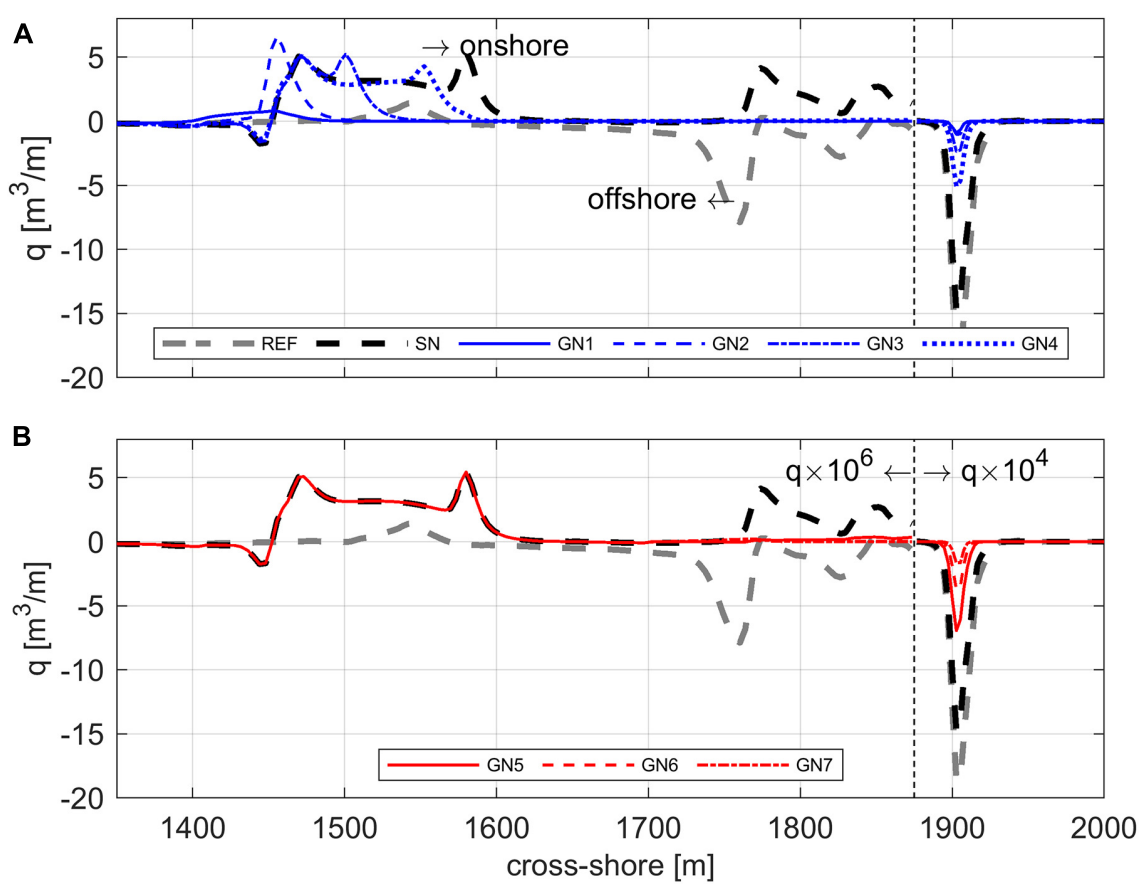

FIGURE 6 | Cross-shore sediment flux for: (A) case REF, SN, and GN1-4; and (B) case GN5-7. Note that the value was amplified for illustration purpose with a factor of $10^{6}$ and $10^{4}$ in seaward and shoreward of $x=1,875 \mathrm{~m}$, respectively. Positive and negative value indicates onshore and offshore directed sediment flux.

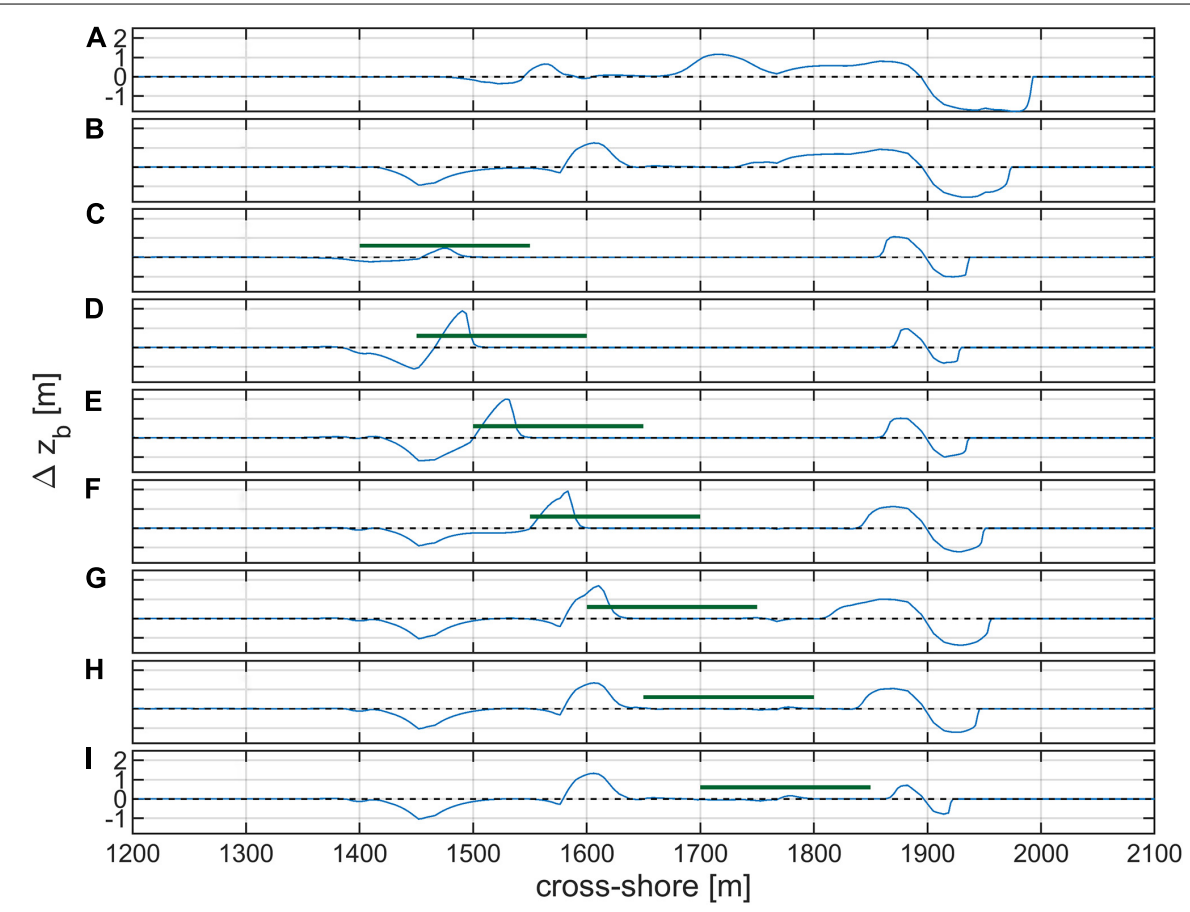

FIGURE 7 | Change of seabed under mild wave condition for 100 days, showing: (A) REF seabed; (B) SN bed; (C-I) GN1-7. Green horizontal line indicates the location of the seagrass meadow.

the seagrass shoot height, Figure $\mathbf{8 A}$ ). The bury ratio of GN1 ranges from -0.75 to 1 , suggesting either root removal or shoot burying. For a seagrass meadow located at more shoreward position, the percentage of burying seagrass meadow reduces. The maximum bury ratio of GN2, GN3, GN4, and GN5 is as high as 4. GN6 and GN7, on the other hand, have bury 

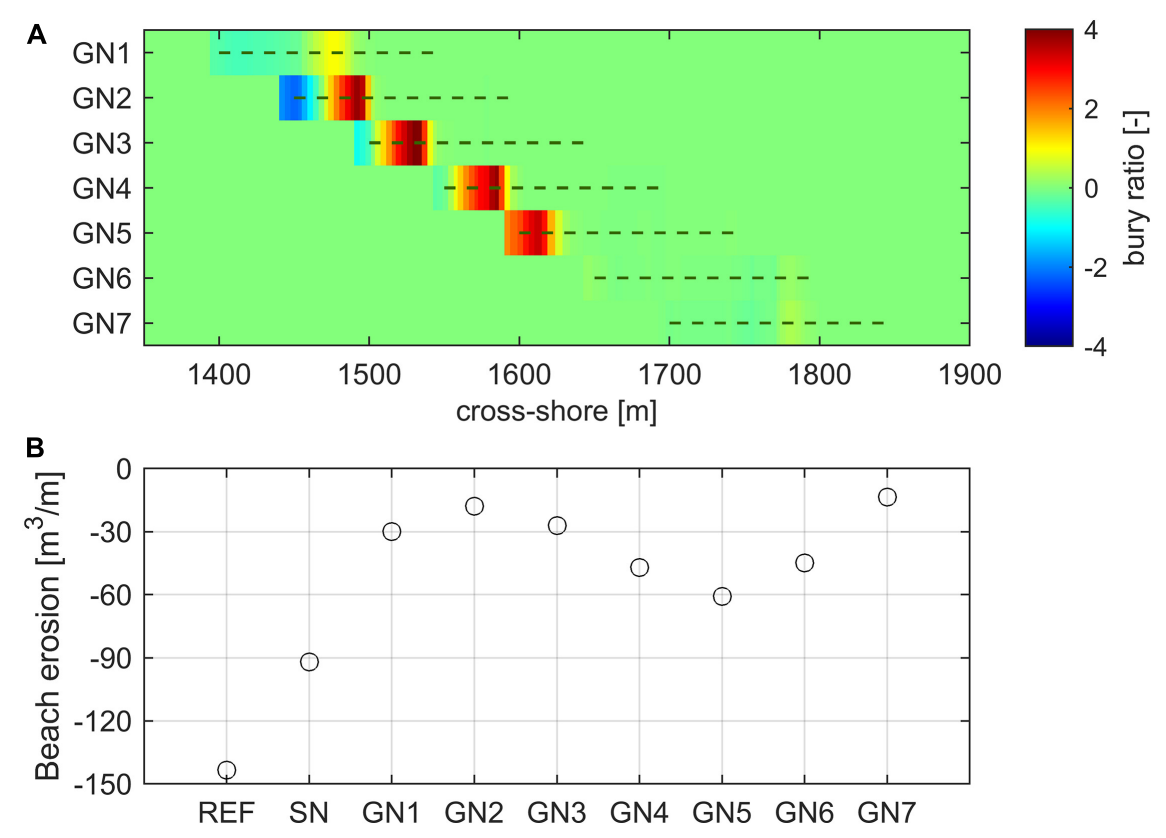

FIGURE 8| The bury ratio of green nourishment (A) and beach erosion under 100 days mild wave condition for all cases (B).

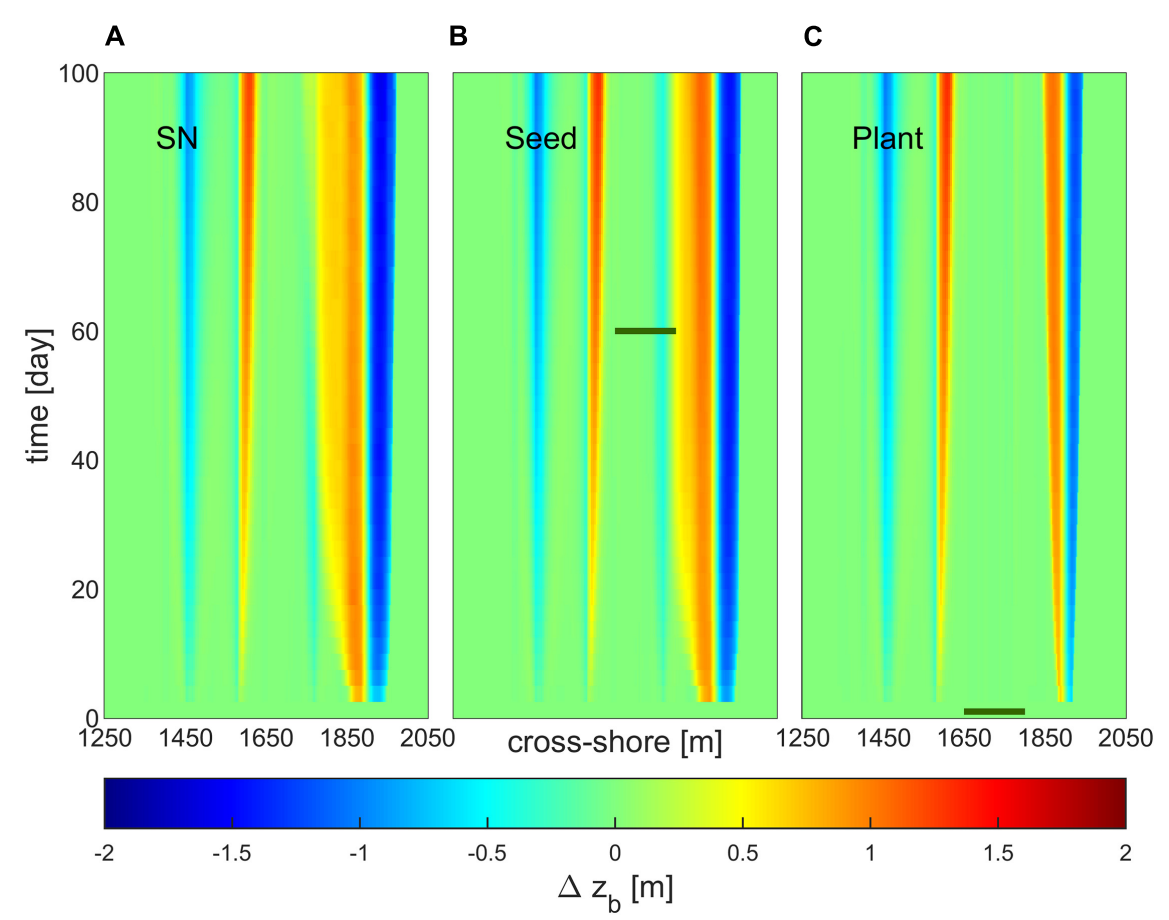

FIGURE 9 | Change of seabed over time for: (A) shoreface nourishment only; (B) seed planting assuming linear growing seagrass; (C) mature seagrass planting. Green lines indicate the range of the seagrass meadow and the mature timing of the plant.

ratio less than 0.2 all over the seagrass meadow and has the least disturbance percentage. For GN1-7, the beach erosion, i.e., defined as integrated sand erosion shoreward of the shoreline (i.e., $x>1,905 \mathrm{~m}$ ), were significantly reduced compared with the REF case, i.e., from $150 \mathrm{~m}^{3} / \mathrm{m}$ to less than $60 \mathrm{~m}^{3} / \mathrm{m}$
(Figure 8B). Meanwhile, the landward limit of the beach erosion in GN1-7 has been limited to $x=1,926 \mathrm{~m}$ instead of $x=1,971 \mathrm{~m}$ in the REF case, which agrees with the seaward shift of both incoming wave and IG wave at the shoreline. Of the GN1-7 cases, GN7 had the least erosion whereas GN5 has the most erosion. 
The severity of beach erosion highly correlated with the wave height and IG wave height at the coast (Figures 3, 5).

\section{Exploring the Seagrass Planting Technique: Seed Planting}

Seed planting (GN6S) generated similar results to the deployment of pre-grown plants at the beginning of the simulation (GN6) (Figure 9). Most of the seeded region reached maturity at the end of 100 days simulation. The seed planting technique was implemented with an altered vegetation module, in which a slow linear growth rate was used for the first 10 days, i.e., $5 \mathrm{~cm}$ shoot height for the first 10 days, and a faster growth rate for another 50 days, i.e., $45 \mathrm{~cm}$ shoot growth for the following 50 days. The seagrass was supposed to reach a mature state on the 60th day after planting (i.e., $\mathrm{T}_{\mathrm{v}, \mathrm{m}}=60$ days). Erosion at the shoreward end of the seagrass meadow is induced by the shoaling and breaking of wave at that region (i.e., shore breaking zone of SN in Figure 3) before the seagrass is mature enough to provide protection, which is the reason why not all seagrass reached maturity. In locations where the seagrass developed to maturity, wave energy was dissipated by vegetation and the seabed remained stable afterward.

\section{Sensitivity of Green Nourishment to Wave Conditions and Seagrass Parameters}

Seagrass meadow was sensitive to the offshore wave conditions and was vulnerable to more energetic wave of big height and long period (see Figure 10). Although wave reaching the seagrass meadow had been significantly damped, the morphodynamics was very dynamic. With increasing offshore wave height and period (i.e., GN6W2-6), both the seaward and shoreward edge of the meadow were buried at the end of 100 days simulation. For the most energetic wave (i.e., GN6W6), the entire seagrass meadow was buried. The meadow average bury ratio at the end of the simulation jumped to over 1.0 as wave height increased from 2.5 to $3 \mathrm{~m}$ along with wave period increased from 9.0 to $9.5 \mathrm{~s}$, suggesting an appropriate wave condition to be under $3 \mathrm{~m}$ for the growth of seagrass. Taking average bury ratio of 1.0 as a survival criterion, seagrass meadow of GN6W3-6 can survive for 85, 60, 40 , and 28 days after the planting.

Mature seagrass of high leaf and dense shoot provides strongest attenuation to wave height and best protection to the beach (see Figures 11, 12). With higher $a_{h}$, the attenuation effect of seagrass meadow on the incoming wave and infragravity waves increases. $\mathrm{H}_{\mathrm{S}}$ at the landward edge of the seagrass meadow reduces from $0.97 \mathrm{~m}$ of GN6a1 to $0.31 \mathrm{~m}$ of GN6a4, while $\mathrm{H}_{\mathrm{IG}}$ reduces from 0.27 to $0.17 \mathrm{~m}$. The effect of seagrass shoot density is similar to that of seagrass height, i.e., stronger attenuation and better protection with denser seagrass meadow. Under mild waves, all seagrass meadows examined seem to survive at the end of the 100 days simulation, except for seagrass with lowest leaf (GN6a1) and most sparse shoot (GN6n1) where erosion and deposition was observed at the shoreward edge of the meadow. The landward limit of beach erosion and the amount of beach erosion are highly related to the attenuation effect of the seagrass meadow. With better protection there is less beach erosion and limited eroded area. Although seagrass of lowest leaf (GN6a1) and most sparse shoot (GN6n1) provide the least protection to the coast, the beach erosion is still much less than the one without seagrass (SN), i.e., $72 \mathrm{~m}^{3} / \mathrm{m}$ for the former two cases and $92 \mathrm{~m}^{3} / \mathrm{m}$ for the latter case.

\section{Resilience of Green Nourishment to Storm Event}

The green nourishment provides protection to the coast against storm attack, by damping the wave and reducing beach erosion (Figures 13, 14). The morphological response of the seabed to a 1-week storm event was examined for four cases (REF, SN, GN6, and GN6E). The final seabed of the 100 days simulation was taken as the pre-storm profile of the simulation. A maximum of $1.55 \mathrm{~m}$ reduction in the wave height (i.e., at $x=1,721 \mathrm{~m}$ ) was observed for GN6 with respect to the REF case, which accounted for $58 \%$ of the wave height on REF bed. Seagrass also leads to significant reduction on IG wave height (Figure 13B). The IG wave height kept reducing over the seagrass meadow. Peak IG wave height reduced from $1.544 \mathrm{~m}$ for the REF case to $0.947 \mathrm{~m}$ for GN6. The shoreward limit of the erosion was shifted from $x=2,045 \mathrm{~m}$ (REF) to $x=2,000 \mathrm{~m}$ (GN6), preventing approximately a $45 \mathrm{~m}$ wide section of beach from eroding (Figure 13D). The total volume of beach erosion has also been reduced from $200 \mathrm{~m}^{3} / \mathrm{m}$ (REF) to $53 \mathrm{~m}^{3} / \mathrm{m}$ (GN6, Figure 14B). Extending the cross-shore coverage of seagrass meadow from $150 \mathrm{~m}$ (GN6) to $250 \mathrm{~m}$ (GN6E) intensified the protection of the green nourishment, i.e., $0.38 \mathrm{~m}$ lower wave height at $x=1,910 \mathrm{~m}, 0.36 \mathrm{~m}$ lower IG wave height and $17.5 \mathrm{~m}^{3} / \mathrm{m}$ less beach erosion after the 1-week storm event. The seagrass at both the shoreward and seaward margins of the meadow was buried after the storm event. The seaward burial was caused by the shoaling and breaking of waves, and the shoreward burial results from the displacement of sand from the shoreline region. Seagrass in the interior of the meadow was not impacted by the waves or morphological change caused by the storm (Fonseca, 1994). In the GN6 case, $42 \%$ of the seagrass had a bury ratio above 1.0, suggesting a loss of nearly half of the seagrass in the designed storm event. With the enlarged seagrass meadow (GN6E), only $31 \%$ of the seagrass had a bury ratio above 1.0 , suggesting a higher survival rate for seagrass meadow of greater cross-shore length.

\section{Sheltering Effect of the Shoreface Nourishment}

The shoreface nourishment increased the resilience of seagrass meadow through its impacts on wave attenuation and morphological change. A comparison between case GN6 and GREF, which had seagrass meadows in the same cross-shore location but only shoreface nourishment in GN6, shows the nourishment induced a reduction of 0.34 and $1 \mathrm{~m}$ in wave height at the seaward end of the seagrass bed for mild wave and stormy wave, respectively (Figure 15). The IG wave height distribution of GREF is similar to that of the GN6 (not shown). The nourishment created a more sheltered environment for the seagrass. Beach 

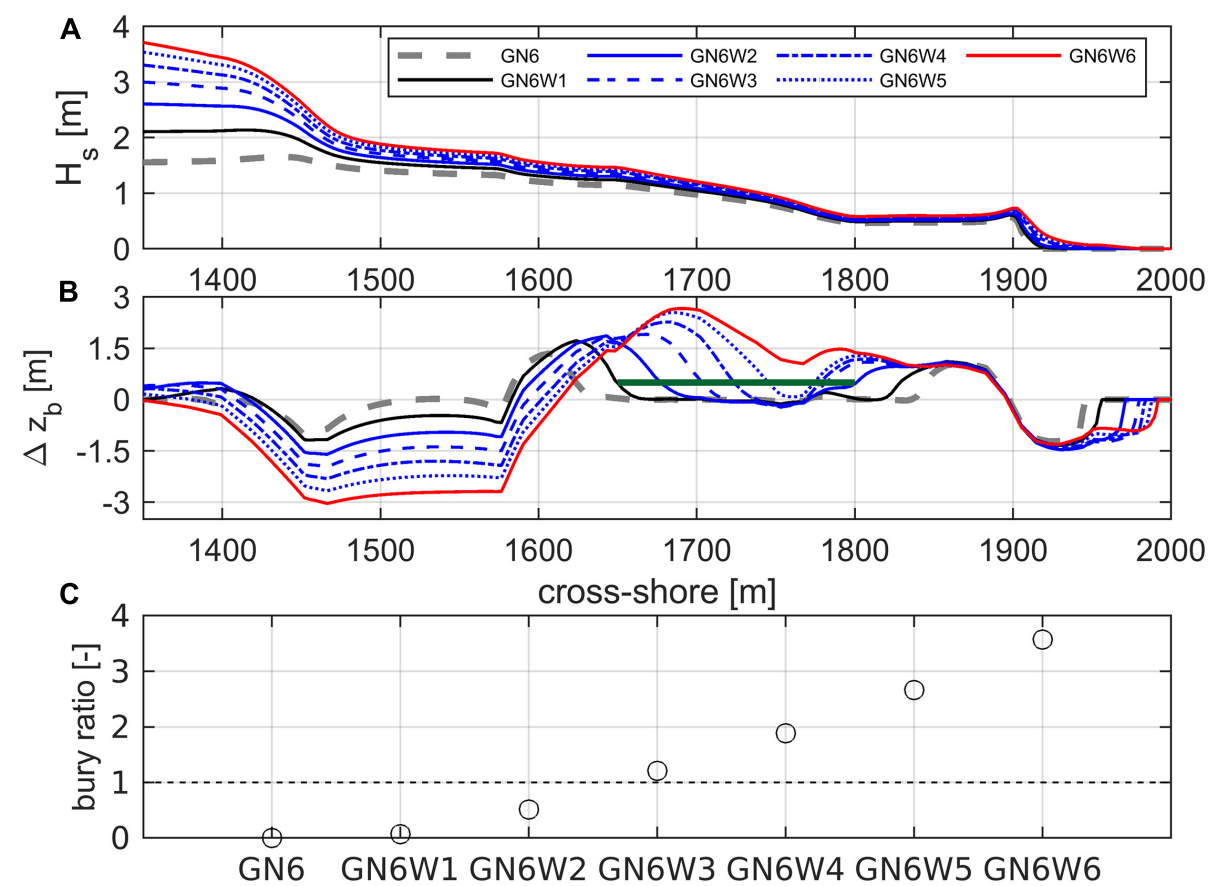

FIGURE 10 | Sensitivity of seagrass to offshore wave conditions, showing: (A) wave height distribution; (B) seabed change after 100 days simulation; and (C) meadow averaged bury ratio.

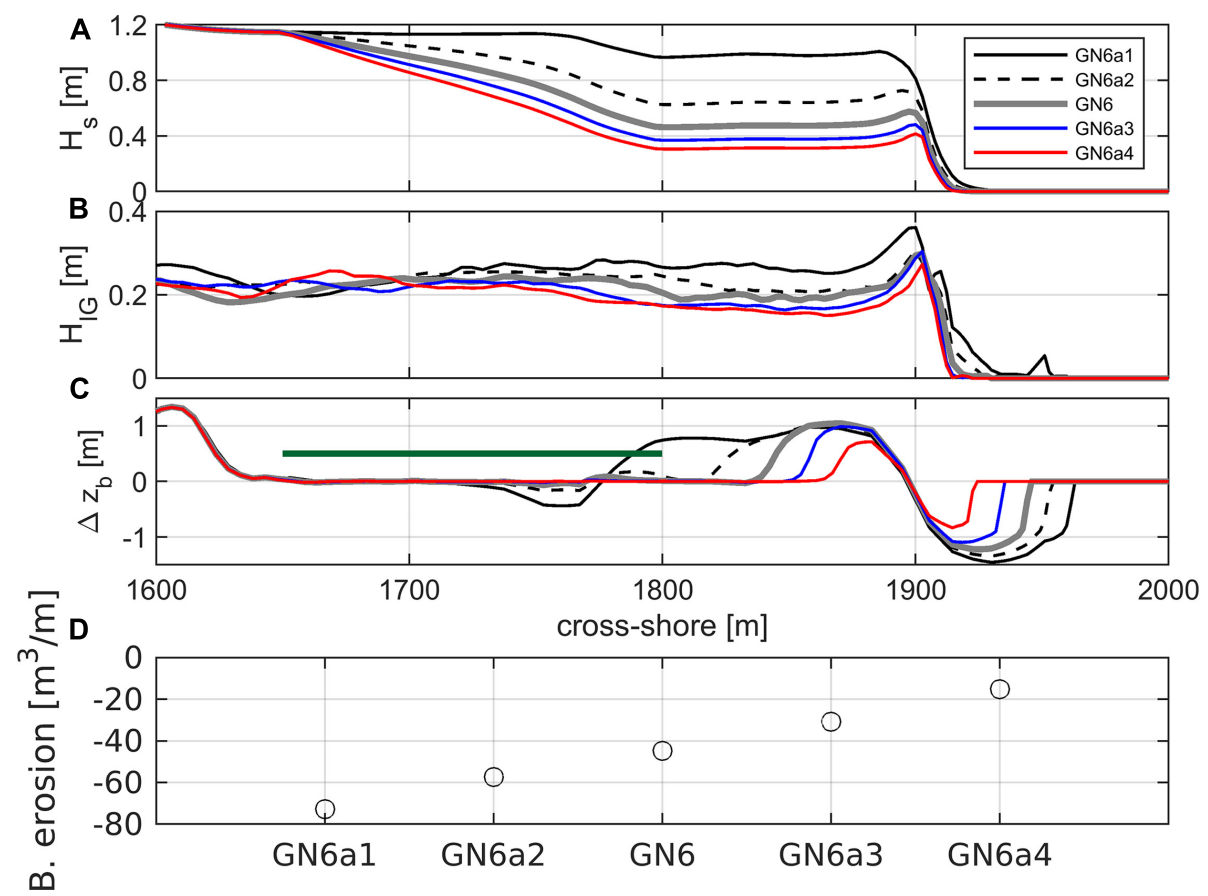

FIGURE 11 | Sensitivity to seagrass height ah, showing: (A) wave height distribution; (B) infragravity wave distribution; (C) seabed change after 100 days simulation; and (D) beach erosion.

erosion after 100 days of mild wave condition was lower in GN6 than GREF, i.e., $44.8 \mathrm{~m}^{3} / \mathrm{m}$ compared with $71.4 \mathrm{~m}^{3} / \mathrm{m}$. Similarly, beach erosion after the storm event was about $91 \mathrm{~m}^{3} / \mathrm{m}$, which was substantially lower than the non-vegetated nourishment reference (REF). After 100 days mild wave condition, the burial analysis of GREF suggests a similar 


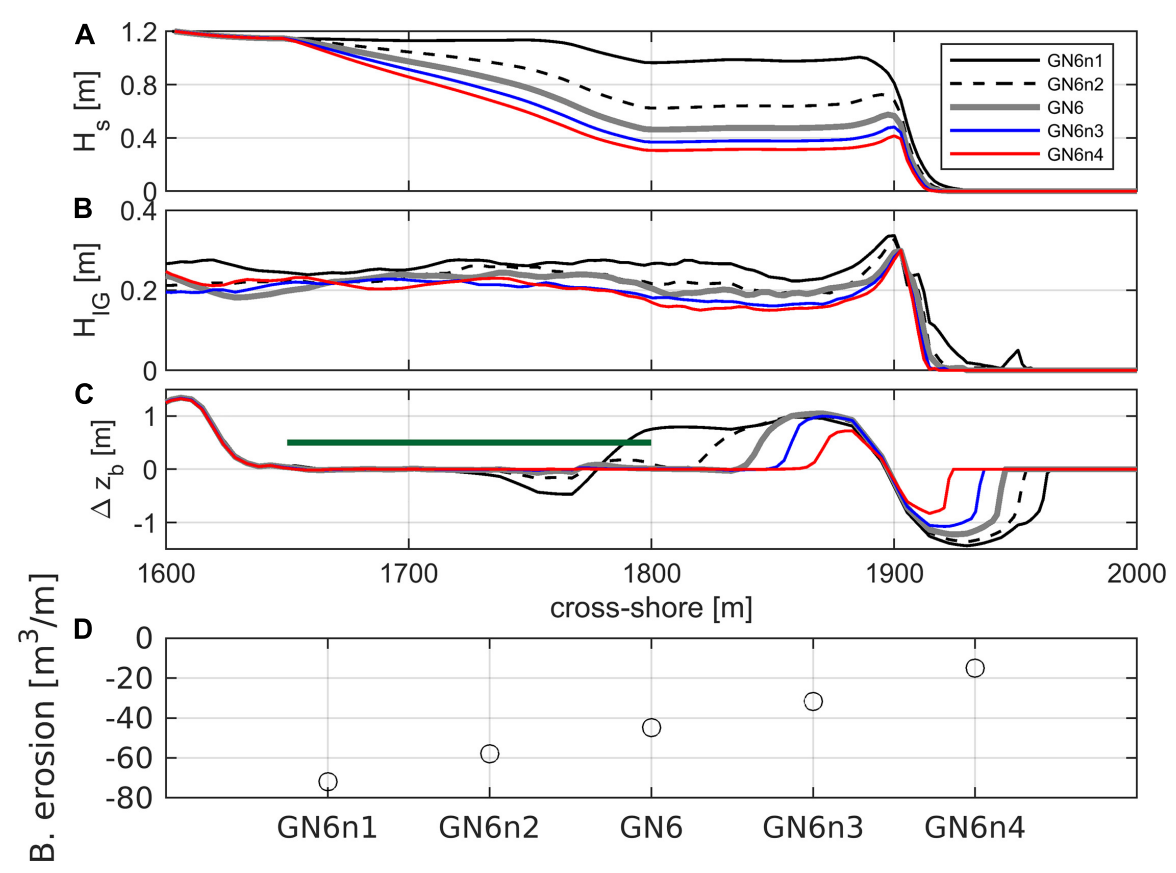

FIGURE 12 | Sensitivity to seagrass shoot density, showing: (A) wave height distribution; (B) infragravity wave distribution; (C) seabed change; and (D) beach erosion.
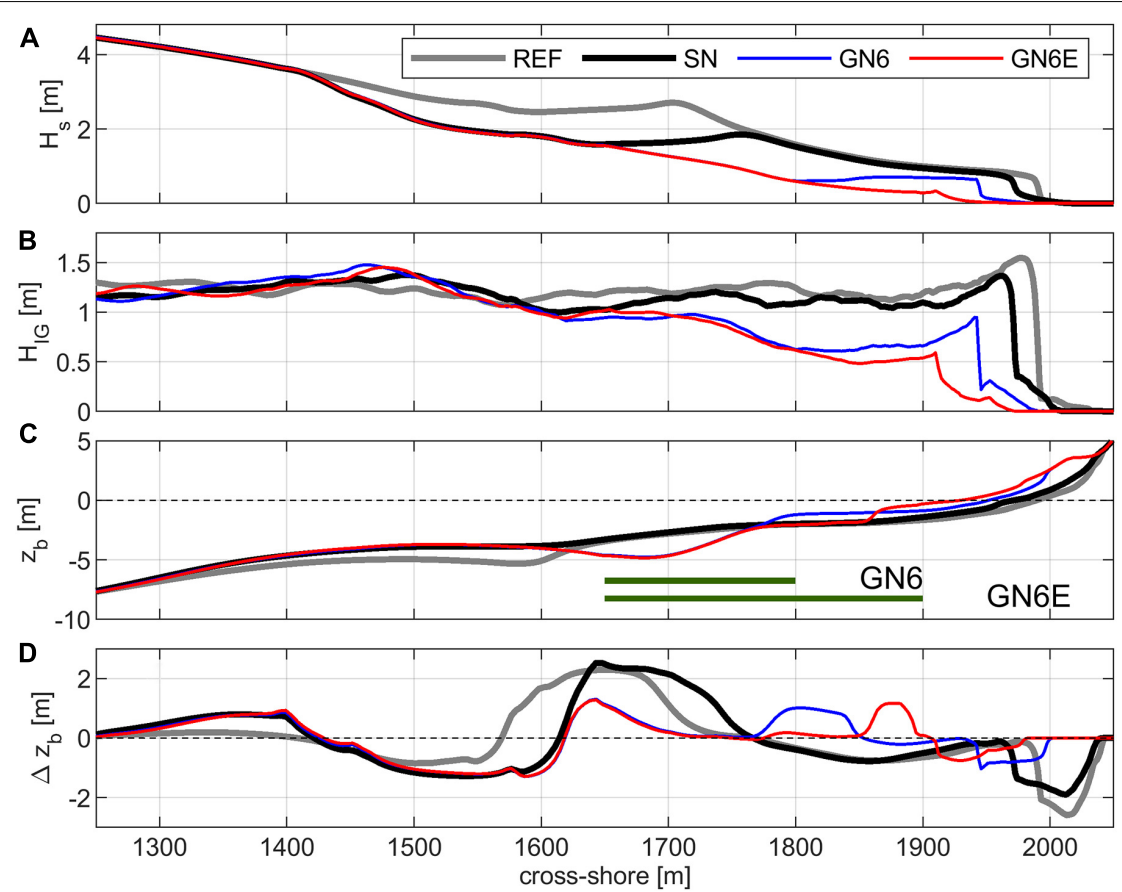

FIGURE 13 Adaptation of green nourishment to a 1-week storm event $\left(H_{m}=5 \mathrm{~m}, T=12 \mathrm{~s}\right)$, showing: (A) wave height simulated on pre-storm seabed profile; (B) infragravity (IG) wave height; (C) seabed after 1 week storm condition; (D) the change of seabed from initial profile (i.e., at the beginning of the 100 days simulation).

survival rate to the GN6 case. However, the storm event caused almost the entire seagrass meadow to be buried in the GREF case, except at the seaward edge where erosion was observed (Figure 15E). Whilst sediment deposition rates were high at the seaward and landward edges of the seagrass meadow in GN6, the interior of the meadow was barely affected, suggest that nourishment would benefit the resilience and survival of seagrass meadow restorations. 

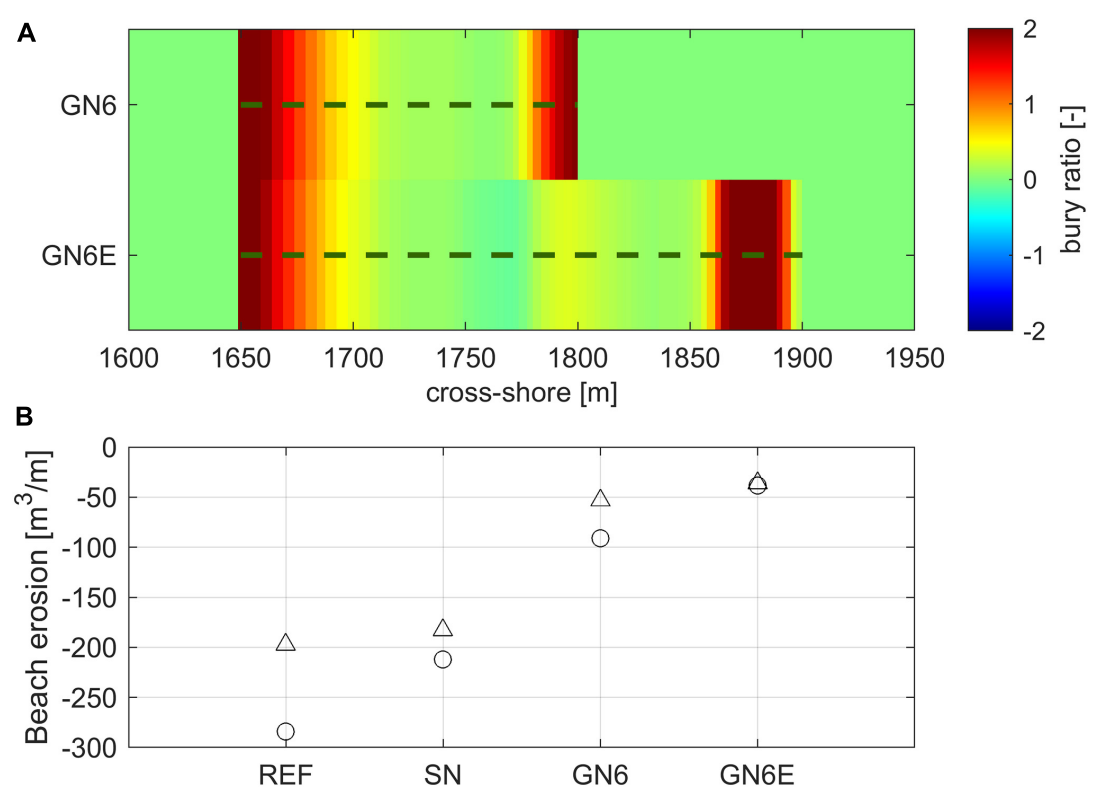

FIGURE 14 | The bury ratio of GN6 and GN6E after the storm are given in panel (A). The beach erosion of REF, SN, GN6, and GN6E are given in panel (B) by integrating the difference of final seabed profile against pre-storm seabed (triangle) and initial seabed (circle).
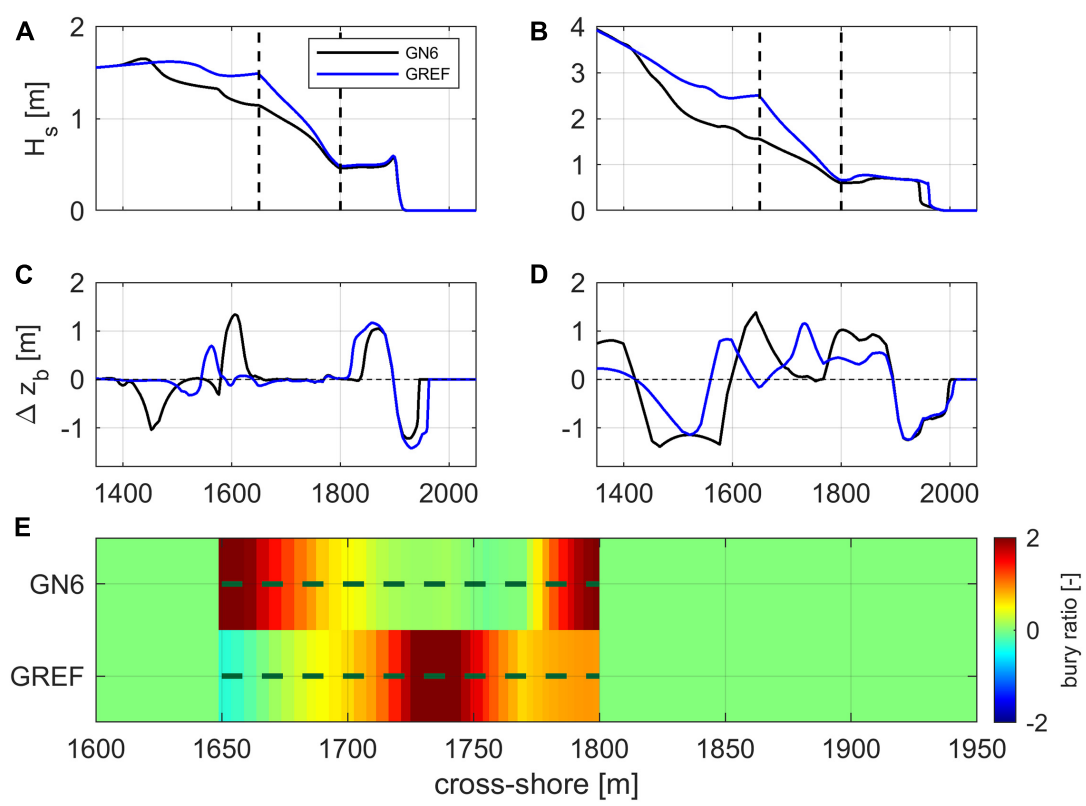

FIGURE 15 | Comparison of case GN6 and GREF, showing: (A) wave height profile under mild wave condition on initial bed profile; (B) wave height profile under storm wave condition on pre-storm profile; (C) seabed change at the end of 100 days simulation; (D) seabed change at the end of storm event; (E) bury analysis for seagrass meadow.

\section{DISCUSSION}

Most of the study runs simulated the impacts of planting of seagrass transplants, however the results of run GN6S suggest that planting seagrass seed is possible if relatively tranquil conditions persist for sufficient length of time for the seed to germinate and to grow to maturity. Seed planting technique has an advantage in greatly reducing the cost compared with mature seagrass transplanting technique (Marion and Orth, 2010; van Katwijk et al., 2016). However, were the seeds to have been sown further shoreward, it seems likely that their development may have been adversely affected by bed change prior to reaching a mature state. Therefore, practical work would be best timed for storm free seasons. The relatively short growth period, i.e., 
month to season, also benefits the recovery of seagrass meadows in between storm events. A hybrid planting with interior seed planting shielded by surrounding mature seagrass transplants would increase the chance of seed germination, as results show that the seagrass burial occurs at the margin of seagrass meadow (Fonseca, 1994). Sensitivity analysis shows that seagrass is able to survive for wave heights under $3 \mathrm{~m}$ for a considerable period. The protection of the coast by seagrass meadow is very sensitive to seagrass parameters. With mature seagrass of high leaf and dense shoots, the beach erosion significantly reduces. In this study, green nourishment with mature seagrass reduces erosion considerably at the shoreline in a severe storm. But to survive through a strong storm event, the size of the seagrass meadow should be sufficiently large (van Katwijk et al., 2016; Paulo et al., 2019).

Although this study shows that the hydrodynamic conditions could be favorable for the implementation of a green nourishment in the nearshore area, field experimentations for the implementation and development of a dense seagrass meadow on an open coast are required to validate the method. One concern is the light penetration in the area landward of the nourishment. For $Z$. marina, depth and light availability are critical determinants of seagrass restoration success (Xu et al., 2020). Insufficient light availability has been identified as one of the primary causes of transplantation failure (Moore et al., 2012; van Katwijk et al., 2016). The amount of suspended sediment in the water mobilized by wave breaking on the nourishment might cause high turbidity, which would limit light penetration to seagrass leaves and restrain its growth and development. However, this problem would become less important as the seagrass grows, and develops into a dense meadow. Several studies have shown that the direct effect of the seagrass meadows on currents, sediment trapping and decreasing resuspension creates a positive feedback circle for the seagrass. The sediment deposition indeed decreases the turbidity, which in turn increases light availability and allows for better growing conditions (de Boer, 2007; Luhar et al., 2010; Xu et al., 2020). As the seagrass meadow becomes more mature and denser, this circle is enhanced.

The characteristics of the substrate might affect seagrass growth. The nutrient content is very important. Research showed that seagrass planted on natural sediment grows better than on the construction sand, owing to higher nutrient content (Tanner and Parham, 2010), which supports the choice of planting seagrass on shoreward native seabed other than on top of the nourishment. Fine grain size might have negative impact on the density of seagrass ( $z$. noltti) as low porosity of sediment affecting the pore-water exchange and leading to a hypoxic condition (Folmer et al., 2012). But this is not a universal law, as different seagrass has various suitabilities on different substrates, and seagrass has been documented on beds from mud to rock (Dahl et al., 2016). Furthermore, the seagrass meadow is found to be able to self-adjust to substrate material size through grain selection (Zhang et al., 2020).

Parameters used in this study were taken from existing XBeach studies including calibrations with both lab test and field observation (Roelvink et al., 2009; van Thiel de Vries, 2009; van
Rooijen et al., 2016). Whilst uncertainty in the model results may arise from parameter choice such as wave energy dissipation and sediment formula (Berard et al., 2017), the protection mechanism of green nourishment through energy dissipation of nourishment and vegetation is likely to be a robust result, because the formulae are standard and in general use, and the trends in sensitivities will be reproducible. Seagrass meadow of various mature status at different cross-shore locations all provide considerable protection to the coast. The wave reduction by green nourishment is up to $80 \%$ under mild wave condition, which is higher than the effect of only seagrass meadow (i.e., $49 \%$ as in Reidenbach and Thomas, 2018). It must also be noted that that the study pertains in particular to North Sea conditions, as a JONSWAP spectrum was used.

As a first step, this study focused on the cross-shore dynamics of green nourishment and adopted a simplistic approach to model seagrass shoots. Future modeling studies should examine the longshore dynamics, i.e., particularly for a coast with strong longshore current induced by oblique wave or macro-tide. The effects of tides will also be significant, especially on coasts with large tidal ranges. Improvement of the representation of seagrass meadows and their effects on wave, current and sediment transport is also desirable (Nepf, 2011; Suzuki et al., 2019). Although the simplistic way of modeling seagrass shoots as rigid sticks in the vegetation module of XBeach is partially corrected by drag coefficients, the modeling of the effects of storms and high wave energy conditions on seagrass meadows (and vice versa) could be improved (van Rooijen et al., 2015, 2018). Furthermore, a failure scheme could be introduced for seagrass destroyed either by strong current or sediment burial in severe storms which could avoid the overestimation of seagrass attenuation under storm weather. Once being eroded or buried, the seagrass can no longer provide protection to the coast, which is not accounted for at the moment. The green nourishment proposed in this study could be combined with other nature-based solutions, such as beach nourishment, salt marsh construction (i.e., the Marconi project at Delfzijl Netherlands; Hu et al., 2015, 2021; Baptist et al., 2021) and mangrove development (Gijsman et al., 2021), to mitigate the coastal erosion.

\section{CONCLUSION}

The results of this study demonstrate that green nourishment has the potential to substantially reduce wave heights and erosion at the shore. The nourishment provides an input of sand into the system and, crucially, creates a morphological feature that generates a sheltered area landward that is conducive to seagrass establishment and growth. In turn, the seagrass stabilizes the sand substrate and reduces wave energy further. Thus, on high energy coastlines, the placement of the nourishment should be adjusted to maximize intense wave breaking to dissipate wave energy. The simulations suggest that the placement of the seagrass along the cross-shore profile affects substantially wave energy and morphological evolution. Whilst restoration on top of the nourishment (GN1) dissipated a large amount of wave energy, 
a shoreward sheltered region may be more effective. The sharp shoreward decrease in the wave height and the sediment flux in GN1 leads to high rates of sand deposition that eventually bury the marginal seagrass. The turbulence and high current velocity at the breaking zone also jeopardize the growth of seagrass. In contrast, seagrass on a shoreward sheltered region experiences a quieter hydrodynamic environment and a more stable seabed, which allows a higher survival rate.

This study shows that green nourishment has potential as a nature-based solution to mitigate coastal erosion. Model results indicate that a seagrass meadow (i) enhances significantly the wave energy dissipation provided by a shoreface nourishment and (ii) can be effective in sediment transport mitigation when implemented in the sheltered nearshore area. Beach foreshore erosion after a storm event is reduced significantly with the protection of green nourishment. Using seed, rather than mature plants, to restore the seagrass meadow is found possible, which would significantly reduce the operation cost of a green nourishment project. This study also highlights the importance of a large seagrass meadow to cope with long-term exposure to mild wave conditions, as well as occasional storms. There are major challenges associated with implementing a green nourishment on an exposed open coast, but this study and the ongoing progress made in seagrass restoration techniques are promising. Future studies and field experiments are crucial to make green nourishment a sustainable, cost-effective and ecological solution to coastal erosion and flooding.

\section{REFERENCES}

Baptist, M. J., Dankers, P., Cleveringa, J., Sittoni, L., Willemsen, P. W. J. M., van Puijenbroek, M. E. B., et al. (2021). Salt marsh construction as a naturebased solution in an estuarine social-ecological system. Nature-Based Solutions 1:100005. doi: 10.1016/j.nbsj.2021.100005

Berard, N. A., Mulligan, R. P., da Silva, A. M. F., and Dibajnia, M. (2017). Evaluation of XBeach performance for the erosion of a laboratory sand dune. Coastal Eng. 125, 70-80. doi: 10.1016/j.coastaleng.2017.04. 002

Bergillos, R. J., López-Ruiz, A., Principal-Gómez, D., and Ortega-Sánchez, M. (2018). An integrated methodology to forecast the efficiency of nourishment strategies in eroding deltas. Sci. Total Environ. 61, 1175-1184. doi: 10.1016/j. scitotenv.2017.09.197

Boudouresque, C.-F., Blanfuné, A., Pergent, G., and Thibaut, T. (2021). Restoration of seagrass meadows in the mediterranean sea: a critical review of effectiveness and ethical issues. Water 13:1034. doi: 10.3390/w13081034

Chen, W. L., and Dodd, N. (2019). An idealised study for the evolution of a shoreface nourishment. Continental Shelf Res. 178, 15-26. doi: 10.1016/j.csr. 2019.03.010

da Ros, Z., Corinaldesi, C., Dell'Anno, A., Gambi, C., Torsani, F., and Danovaro, R. (2021). Restoration of Cymodocea nodosa seagrass meadows: efficiency and ecological implications. Restoration Ecol. 29:e13313. doi: 10.1111/rec.1 3313

Dahl, M., Deyanova, D., Gütschow, S., Asplund, M. E., Lyimo, L. D., Karamfilov, V., et al. (2016). Sediment properties as important predictors of carbon storage in Zostera marina meadows: a comparison of four european areas. PLoS One 11:e0167493. doi: 10.1371/journal.pone.0167493

de Boer, W. F. (2007). Seagrass-sediment interactions, positive feedbacks and critical thresholds for occurrence: a review. Hydrobiologia 591, 5-24. doi: 10. 1007/s10750-007-0780-9

de Schipper, M. A., de Vries, S., Ruessink, G., de Zeeuw, R. C., Rutten, J., van Gelder-placeMaas, C., et al. (2016). Initial spreading of a mega feeder

\section{DATA AVAILABILITY STATEMENT}

The datasets presented in this study can be found in online repositories. The names of the repository/repositories and accession number(s) can be found below: https://doi.org/10.17862 /cranfield.rd.17005480.v1.

\section{AUTHOR CONTRIBUTIONS}

WC was responsible for the design, simulation, writing, and reviewing of the manuscript. PM was responsible for simulation and writing of the manuscript. RG was responsible for design, supervising, writing, and reviewing of the manuscript. ND was responsible for design, writing, and reviewing of the manuscript. All authors contributed to the article and approved the submitted version.

\section{FUNDING}

This work was supported primarily by the UK Engineering and Physical Science Research Council (EPSRC, Grant EP/T001100/1). Support is also acknowledged from the EPSRC under the MORPHINE project (Grant EP/N007379/1) and the UK Natural Environment Research Council (NERC, Grant $\mathrm{NE} / \mathrm{S} 01232 \mathrm{X} / 1)$.

nourishment: observations of the Sand Engine pilot project. Coastal Eng. 111, 23-38. doi: 10.1016/j.coastaleng.2015.10.011

Dhoop, T., and Mason, T. (2018). Spatial characteristics and duration of extreme wave events around the English coastline. J. Mar. Sci. Eng. 6:14. doi: 10.3390/ jmse6010014

Dissanayake, P., Brown, J., and Karunarathna, H. (2014). Modelling storminduced beach/dune evolution: Sefton coast. CityplaceLiverpool Bay, countryregionUK. Mar. Geol. 357, 225-242. doi: 10.1016/j.margeo.2014.07.013

Elsayed, S. M., and Oumeraci, H. (2017). Effect of beach slope and grainstabilization on coastal sediment transport: an attempt to overcome the erosion overestimation by XBeach. Coastal Eng. 121, 179-196. doi: 10.1016/j.coastaleng. 2016.12.009

Folkard, A. M. (2011). Flow regimes in gaps within stands of flexible vegetation: laboratory flume simulations. Environ. Fluid Mechan. 11, 289-306. doi: 10. 1007/s10652-010-9197-5

Folmer, E. O., van der Geest, M., Jansen, E., Olff, H., Michael Anderson, T., Piersma, T., et al. (2012). Seagrass-Sediment feedback: an exploration using a nonrecursive structural equation model. Ecosystems 15, 1380-1393. doi: 10.1007/ s10021-012-9591-6

Fonseca, M. S. (1994). A Guide to Planting Seagrasses in the Gulf of Mexico. Texas A\&M University Sea Grant College Program, TAMU-SG-94-601. College Station, TX: Texas A\&M University.

Gagnon, K., Christie, H., Didderen, K., Fagerli, C. W., Govers, L. L., Gräfnings, M. L. E., et al. (2021). Incorporating facilitative interactions into small-scale eelgrass restoration—challenges and opportunities. Restoration Ecol. 29:e13398. doi: $10.1111 /$ rec. 13398

Gijsman, R., Horstman, E. M., van der Wal, D., Friess, D. A., Swales, A., and Wijnberg, K. M. (2021). Nature-Based engineering: a review on reducing coastal flood risk with mangroves. Front. Mar. Sci. 8:702412. doi: 10.3389/fmars.2021. 702412

Hamm, L., Capobianco, M., Dette, H. H., Lechuga, A., Spanhoff, R., and Stive, M. J. F. (2002). A summary of European experience with shore nourishment. Coastal Eng. 47, 237-264. 
Hinkel, J., Nicholls, R. J., Tol, R. S. J., Wang, Z. B., Hamilton, J. M., Boot, G., et al. (2013). A global analysis of erosion of sandy beaches and sea-level rise: an application of DIVA. Global Planetary Change 111, 150-158. doi: 10.1016/j. gloplacha.2013.09.002

Hu, Z., Borsje, B. W., van Belzen, J., Willemsen, P. W. J. M., Wang, H., Peng, Y., et al. (2021). Mechanistic modelling of marsh seedling establishment provides a positive outlook for coastal wetland restoration under global climate change. Geophys. Res. Lett. 48:e2021GL095596. doi: 10.1029/2021GL095596

Hu, Z., van Belzen, J., van der Wal, D., Balke, T., Wang, Z. B., Stive, M., et al. (2015). Windows of opportunity for salt marsh vegetation establishment on bare tidal flats: the importance of temporal and spatial variability in hydrodynamic forcing. J. Geophys. Res. Biogeosci. 120, 1450-1469. doi: 10.1002/2014JG002870

Huisman, B. J. A., Walstra, D.-J. R., Radermacher, M., de Schipper, M. A., and Ruessink, B. G. (2019). Observations and modelling of shoreface nourishment behaviour. J. Mar. Sci. Eng. 7:59. doi: 10.3390/jmse7030059

Irving, A. D., Tanner, J. E., and Collings, G. J. (2014). Rehabilitating seagrass by facilitating recruitment: improving chances for success. Restoration Ecol. 22, 134-141. doi: 10.1111/rec.12036

Izaguirre, C., Méndez, F. J., Menéndez, M., and Losada, placeI. J. (2011). Global extreme wave height variability based on satellite data. Geophys. Res. Lett. 38:L10607. doi: 10.1029/2011GL047302

Jin, H., Do, K., Shin, S., and Cox, D. (2021). Process-Based model prediction of coastal dune erosion through parametric calibration. J. Mar. Sci. Eng. 9:635. doi: 10.3390/jmse 9060635

Lashley, C. H., Roelvink, D., van Dongeren, A., Buckley, M. L., and Lowe, R. J. (2018). Nonhydrostatic and surfbeat model predictions of extreme wave runup in fringing reef environments. Coastal Eng. 137, 11-27. doi: 10.1016/j. coastaleng.2018.03.007

Luhar, M., Coutu, S., Infantes, E., Fox, S., and Nepf, H. (2010). Wave-induced velocities inside a model seagrass bed. J. Geophys. Res. Oceans 115:C12. doi: 10.1029/2010JC006345

Marion, S. R., and Orth, R. J. (2010). Innovative techniques for large-scale seagrass restoration using Zostera marina (eelgrass) Seeds. Restoration Ecol. 18, 514-526. doi: 10.1111/j.1526-100X.2010.00692.x

Masselink, G., and Russell, P. (2008). Coastal Erosion and Coastal Geomorphology. MCCIP (Marine Climate Group Impacts Partnership) Annual Report Card 2007-2008 Scientific Review. Plymouth: University of Plymouth.

McCall, R. T., van Thiel, de Vries, J. S. M., Plant, N. G., van Dongeren, A. R., Roelvink, J. A., et al. (2010). Two-dimensional time dependent hurricane overwash and erosion modeling at placeSanta Rosa Island. Coastal Eng. 57, 668-683. doi: 10.1016/j.coastaleng.2010.02.006

Mendez, F. J., and Losada, placeI. J. (2004). An empirical model to estimate the propagation of random breaking and nonbreaking waves over vegetation fields. Coastal Eng. 51, 103-118. doi: 10.1016/j.coastaleng.2003.11.003

Menéndez, M., and Woodworth, P. L. (2010). Changes in extreme high water levels based on a quasi-global tide-gauge data set. J. Geophys. Res. Oceans 115:C10011. doi: 10.1029/2009JC005997

Montgomery, J. M., Bryan, K. R., Mullarney, J. C., and Horstman, E. M. (2019). Attenuation of storm surges by coastal mangroves. Geophys. Res. Lett. 46, 2680-2689. doi: 10.1029/2018GL081636

Moore, K. A., Shields, E. C., Parrish, D. B., and Orth, R. J. (2012). Eelgrass survival in two contrasting systems: role of turbidity and summer water temperatures. Mar. Ecol. Prog. Series 448, 247-258. doi: 10.3354/meps09578

Nepf, H. M. (2011). Flow and transport in regions with aquatic vegetation. Ann. Rev. Fluid Mech. 44, 123-142. doi: 10.1146/annurev-fluid-120710- 101048

Nicholls, R. J., Wong, P. P., Burkett, V., Codignotto, J. O., Hay, J., McLean, R. F., et al. (2007). Coastal Systems and Low-lying Areas. Cambridge: Cambridge University Press.

Ondiviela, B., Losada, placeI. J., Lara, J. L., Maza, M., Galván, C., Bouma, T. J., et al. (2014). The role of seagrasses in coastal protection in a changing climate. Coastal Eng. 87, 158-168. doi: 10.1016/j.coastaleng.2013.11.005

Paulo, D., Cunha, A. H., Boavida, J., Serrão, E. A., Gonçalves, E. J., and Fonseca, M. (2019). PlaceNameOpen coast seagrass restoration. can we do it? large scale seagrass transplants. Front. Mar. Sci. 6:52. doi: 10.3389/fmars.2019.00052

Quataert, E., Storlazzi, C., van Rooijen, A., Cheriton, O., and van Dongeren, A. (2015). The influence of coral reefs and climate change on wave-driven flooding of tropical coastlines. Geophys. Res. Lett. 42, 6407-6415. doi: 10.1002/ 2015GL064861
Reidenbach, M. A., and Thomas, E. L. (2018). Influence of the Seagrass, Zostera marina, on wave attenuation and bed shear stress within a shallow coastal bay. Front. Mar. Sci. 5:397. doi: 10.3389/fmars.2018.00397

Roelvink, D., McCall, R., Mehvar, S., Nederhoff, K., and Dastgheib, A. (2018). Improving predictions of swash dynamics in XBeach: The role of groupiness and incident-band runup. Coastal Eng. 134, 103-123. doi: 10.1016/j.coastaleng. 2017.07.004

Roelvink, D., Reniers, A., van Dongeren, A., van Thiel, de Vries, J., McCall, R., et al. (2009). Modelling storm impacts on beaches, dunes and barrier islands. Coastal Eng. 56, 1133-1152. doi: 10.1016/j.coastaleng.2009.08.006

Roelvink, J. A. (1993). Dissipation in random wave groups incident on a beach. Coastal Eng. 19, 127-150. doi: 10.1016/0378-3839(93)90021-y

Sembiring, L., van Ormondt, M., van Dongeren, A., and Roelvink, D. (2015). A validation of an operational wave and surge prediction system for the Dutch coast. Nat. Hazards Earth Syst. Sci. 15, 1231-1242. doi: 10.5194/nhess- 15-12312015

Stronkhorst, J., Huisman, B., Giardino, A., Santinelli, G., and CityplaceSantos, F. D. (2018). Sand nourishment strategies to mitigate coastal erosion and sea level rise at the coasts of CityHolland (The Netherlands) and Aveiro (countryregionplacePortugal) in the 21st century. Ocean Coastal Manag. 156, 266-276. doi: 10.1016/j.ocecoaman.2017.11.017

Suzuki, T., Hu, Z., Kumada, K., Phan, L. K., and Zijlema, M. (2019). Nonhydrostatic modeling of drag, inertia and porous effects in wave propagation over dense vegetation fields. Coastal Eng. 149, 49-64. doi: 10.1016/j.coastaleng. 2019.03.011

Tan, Y. M., Dalby, O., Kendrick, G. A., Statton, J., Sinclair, E. A., Fraser, M. W., et al. (2020). Seagrass restoration is possible: insights and lessons from Australia and New Zealand. Front. Mar. Sci. 7:617. doi: 10.3389/fmars.2020. 00617

Tanner, C. E., and Parham, T. (2010). Growing Zostera marina (eelgrass) from seeds in land-based culture systems for use in restoration projects. Restoration Ecol. 18, 527-537. doi: 10.1111/j.1526-100X.2010.00693.x

Temmerman, S., Meire, P., Bouma, T. J., Herman, P. M. J., Ysebaert, T., and de Vriend, H. J. (2013). Ecosystem-based coastal defence in the face of global change. Nature 504, 79-83. doi: 10.1038/nature12859

Tyler-Walters, H. (2008). "Zostera (Zostera) marina Common eelgrass," in Marine Life Information Network: Biology and Sensitivity Key Information Reviews, [On-line], eds H. Tyler-Walters and K. Hiscock (Plymouth: Marine Biological Association of the United Kingdom).

Unsworth, R. K. F., Bertelli, C. M., Cullen-Unsworth, L. C., Esteban, N., Jones, B. L., Lilley, R., et al. (2019). Sowing the seeds of seagrass recovery using hessian bags. Front. Ecol. Evol. 7:311. doi: 10.3389/fevo.2019.00311

van Dongeren, A., Lowe, R., Pomeroy, A., Trang, D. M., Roelvink, D., Symonds, G., et al. (2013). Numerical modeling of low-frequency wave dynamics over a fringing coral reef. Coastal Eng. 73, 178-190. doi: 10.1016/j.coastaleng.2012.1 1.004

van Duin, M. J. P., Wiersma, N. R., Walstra, D. J. R., van Rijn, L. C., and Stive, M. J. F. (2004). Nourishing the shoreface: observations and hindcasting of the Egmond case. The country-regionplaceNetherlands. Coastal Eng. 51, 813-837. doi: 10.1016/j.coastaleng.2004.07.011

van Katwijk, M. M., Thorhaug, A., Marbà, N., Orth, R. J., CityplaceDuarte, C. M., Kendrick, G. A., et al. (2016). Global analysis of seagrass restoration: the importance of large-scale planting. J. Appl. Ecol. 53, 567-578. doi: 10.1111/ 1365-2664.12562

van Rijn, L. C. (2007). Unified view of sediment transport by currents and waves. i: initiation of motion, bed roughness, and bed-load transport. J. Hydraulic Eng. 133, 649-667.

van Rooijen, A. A., McCall, R. T., van Thiel, de Vries, J. S. M., van Dongeren, A. R., Reniers, A. J. H. M., et al. (2016). Modeling the effect of wave-vegetation interaction on wave setup. J. Geophys. Res. Oceans 121, 4341-4359. doi: 10.1002/ 2015JC011392

Van Rooijen, A. A., Van Thiel de Vries, J. S. M., McCall, R. T., Van Dongeren, A. R., Roelvink, J. A., and Reniers, A. J. H. M. (2015). "Modeling of wave attenuation by vegetation with XBeach," in E-Proceedings of the 36th IAHR World Congress, 2015, Vol. 7, The Hague.

van Rooijen, A., Lowe, R., Ghisalberti, M., Conde-Frias, M., and Tan, L. (2018). Predicting current-induced drag in emergent and submerged aquatic vegetation canopies. Front. Mar. Sci. 5:449. doi: 10.3389/fmars.2018.00449 
van Thiel de Vries, J. S. M. (2009). Dune Erosion During Storm Surges. Amsterdam: IOS Press.

van Zelst, V. T. M., Dijkstra, J. T., van Wesenbeeck, B. K., Eilander, D., Morris, E. P., Winsemius, H. C., et al. (2021). Cutting the costs of coastal protection by integrating vegetation in flood defences. Nat. Commun. 12:6533. doi: 10.1038/ s41467-021-26887-4

Wear, R. J., Tanner, J. E., and Hoare, S. L. (2010). Facilitating recruitment of Amphibolis as a novel approach to seagrass rehabilitation in hydrodynamically active waters. Mar. Freshwater Res. 61, 1123-1133. doi: 10.1071/mf09314

Wijnberg, K. M. (2002). Environmental controls on decadal morphologic behaviour of the CityplaceHolland coast. Mar. Geol. 189, 227-247. doi: 10.1016/ S0025-3227(02)00480-2

Williams, A. T., Rangel-Buitrago, N., Pranzini, E., and Anfuso, G. (2018). The management of coastal erosion. Ocean Coastal Manag. 156, 4-20. doi: 10.1016/ j.ocecoaman.2017.03.022

Xu, S., Wang, P., Wang, F., Liu, P., Liu, B., Zhang, X., et al. (2020). In situ Responses of the Eelgrass Zostera marina L. to water depth and light availability in the context of increasing coastal water turbidity: implications for conservation and restoration. Front. Plant Sci. 11:582557. doi: 10.3389/fpls.2020.582557

Zhang, J., Lei, J., Huai, W., and Nepf, H. (2020). Turbulence and particle deposition under steady flow along a submerged seagrass meadow. J. Geophys. Res. Oceans 125:e2019JC015985. doi: 10.1029/2019JC015985
Zhu, Z., Vuik, V., Visser, P. J., Soens, T., van Wesenbeeck, B., van de Koppel, J., et al. (2020). Historic storms and the hidden value of coastal wetlands for nature-based flood defence. Nat. Sustainabil. 3, 853-862. doi: 10.1038/s41893020-0556-z

Conflict of Interest: The authors declare that the research was conducted in the absence of any commercial or financial relationships that could be construed as a potential conflict of interest.

Publisher's Note: All claims expressed in this article are solely those of the authors and do not necessarily represent those of their affiliated organizations, or those of the publisher, the editors and the reviewers. Any product that may be evaluated in this article, or claim that may be made by its manufacturer, is not guaranteed or endorsed by the publisher.

Copyright (c) 2022 Chen, Muller, Grabowski and Dodd. This is an open-access article distributed under the terms of the Creative Commons Attribution License (CC BY). The use, distribution or reproduction in other forums is permitted, provided the original author(s) and the copyright owner(s) are credited and that the original publication in this journal is cited, in accordance with accepted academic practice. No use, distribution or reproduction is permitted which does not comply with these terms. 